\title{
54. CHEMOBIOSTRATIGRAPHY OF THE CRETACEOUS/PALEOCENE BOUNDARY AT SITE 750, SOUTHERN KERGUELEN PLATEAU ${ }^{1}$
}

\author{
James C. Zachos, ${ }^{2}$ Marie-Pierre Aubry, ${ }^{3,4}$ William A. Berggren, ${ }^{4}$ Thomas Ehrendorfer, ${ }^{4}$ Franz Heider, ${ }^{5}$ \\ and Kyger C Lohmann ${ }^{2}$
}

\begin{abstract}
An integrated biostratigraphic and stable isotope investigation was conducted on a high-latitude sequence across the Cretaceous/Paleogene (K/P) boundary recovered in Hole $750 \mathrm{~A}$ in the southern Indian Ocean. The sequence consists of nannofossil chalk and is discontinuous across the boundary; missing is an estimated $0.3-\mathrm{m} . \mathrm{y}$. late Maestrichtian and early Danian interval. Nonetheless, because calcareous nannofossil Zones NP1 and NP2 are well-developed, micropaleontological studies of the sequence have yielded a detailed record of Danian high-latitude microplankton evolution. In addition, stable carbon isotope analyses of planktonic and benthic foraminifer and bulk samples provide a record of late Maestrichtian and early Danian surface- and deep-water carbon isotope variations. Together, the carbon isotope and carbonate accumulation records serve as an index of regional marine net productivity across the boundary.

Earliest Danian nannoplankton assemblages consisted mainly of persistent genera that were generally rare or absent in the Upper Cretaceous at Hole 750A. However, by 0.5-0.6 m.y. after the boundary, newly evolving Danian taxa became dominant. The turnover in nannofossil assemblages was accompanied by significant changes in rates of net productivity as gauged by carbon isotope distributions and carbonate accumulation rates. During the period dominated by persistent taxa, net productivity was extremely low, as reflected by the absence of vertical $\delta^{13} \mathrm{C}$ gradients and reduced carbonate accumulation rates. Later in the Danian, as new species evolved and flourished, vertical $\delta^{13} \mathrm{C}$ gradients reappeared and carbonate accumulation rates increased, signaling partial recovery of net productivity in this region. The absolute timing and magnitude of late Maestrichtian and early Danian biotic and geochemical changes in the southern Indian Ocean were similar to those recorded in other pelagic K/P boundary sequences from low- and mid-latitude Atlantic and Pacific sites, indicating that these events were ubiquitous.
\end{abstract}

\section{INTRODUCTION}

During Ocean Drilling Program (ODP) Leg 120 to the Southern Indian Ocean, an expanded pelagic Cretaceous/ Paleocene (K/P) boundary sequence was recovered at Site 750 on the Kerguelen Plateau (Fig. 1) $\left(57^{\circ} 35.54^{\prime} \mathrm{S} ; 81^{\circ} 14.42^{\prime} \mathrm{E}\right)$. The K/P boundary was encountered at $350 \mathrm{mbsf}$, where an upper Maestrichtian white chalk (Subunit IHA) unconformably underlies a lower Danian gray chalk that grades upward into a white chalk (Unit H). The hiatus is estimated to be 0.3 m.y. (Ehrendorfer and Aubry, this volume). Because it represents one of the few $\mathrm{K} / \mathrm{P}$ boundary sequences recovered from subpolar regions, the boundary sequence at Site 750 provides critical constraints on the timing and extent of post-boundary evolution of high-latitude biota and ocean chemistry.

Investigations of pelagic $\mathrm{K} / \mathrm{P}$ boundary sequences from low and middle latitudes have demonstrated that the majority of Late Cretaceous planktonic foraminifers and calcareous nannofossils rapidly disappeared at or near the $\mathrm{K} / \mathrm{P}$ boundary (e.g., Thierstein, 1981; Smit, 1977, 1982; Perch-Nielsen et al., 1982; Gerstel et al., 1987; Keller, 1989a, 1989b), an event

${ }^{1}$ Wise, S. W., Jr., Schlich, R., et al., 1992. Proc. ODP, Sci. Results, 120: College Station, TX (Ocean Drilling Program).

2 Department of Geological Sciences, 1006 C. C. Little Building, University of Michigan, Ann Arbor, MI 48109-1063, U.S.A.

${ }^{3}$ URA 11, Université Claude Bernard, Département des Sciences de la Terre, 27-43 Bd. du 11 Novembre, 69622 Villeurbanne Cedex, France.

${ }^{4}$ Department of Geology and Geophysics, Woods Hole Oceanographic Institution, Quissett Campus, Woods Hole, MA 02543, U.S.A.

${ }^{5}$ Geophysics Laboratory, Department of Physics, University of Toronto, Toronto, Ontario M5S 1A7, Canada (current address: Institut für Allgemeine und Angewandte Geophysik, Ludwig-Maximilians-Universităt, Theresienstrasse 41, 8000 München 2, Federal Republic of Germany). accompanied by a rapid collapse of vertical carbon isotope gradients as well as a several-fold decrease in biogenic carbonate accumulation rates (Hsü et al., 1982a, 1982b; Shackleton et al., 1984; Zachos and Arthur, 1986; Herbert and D'Hondt, 1990). The geochemical anomalies were thought to reflect a near-complete cessation of global marine productivity brought about by the rapid demise of plankton.

Compared with the apparent suddenness of boundary extinctions, the subsequent recovery of marine biota and fertility appears to have progressed very slowly (>500 k.y.). The earliest Danian nannofossil assemblages were composed of species that belonged mainly to persistent genera, most of which were dominant for several hundred thousand years after the boundary until they were supplanted by species of incoming genera (e.g., Thierstein, 1981; Perch-Nielsen, 1979; Perch-Nielsen et al., 1982). Similarly, planktonic foraminifer assemblages consisted mainly of small trochospiral and serial forms that showed extreme instability and constant turnover for at least 0.5-1.0 m.y after the boundary (e.g., Smit, 1982; Gerstel et al., 1987). Depth stratification of planktonic foraminifer was not fully reestablished until the late Paleocene (Corfield and Granlund, 1988). Recovery of net productivity, as measured by stable carbon isotopes and carbonate accumulation rates, began $\sim 0.4-0.5 \mathrm{~m}$.y. after the boundary (e.g., Zachos et al., 1989).

Until recently, many of the pelagic sequences from which these patterns were described were recovered from low- to mid-latitude regions. Thus, the general pattern of plankton extinction and evolution across the $\mathrm{K} / \mathrm{P}$ boundary at high latitudes was unknown and assumed to be similar to that for lower latitudes. The first high-latitude pelagic $\mathrm{K} / \mathrm{P}$ boundary sequence was recovered in Site 690 on Maud Rise in the Southern Ocean during ODP Leg 113 (Barker, Kennett, et al., 


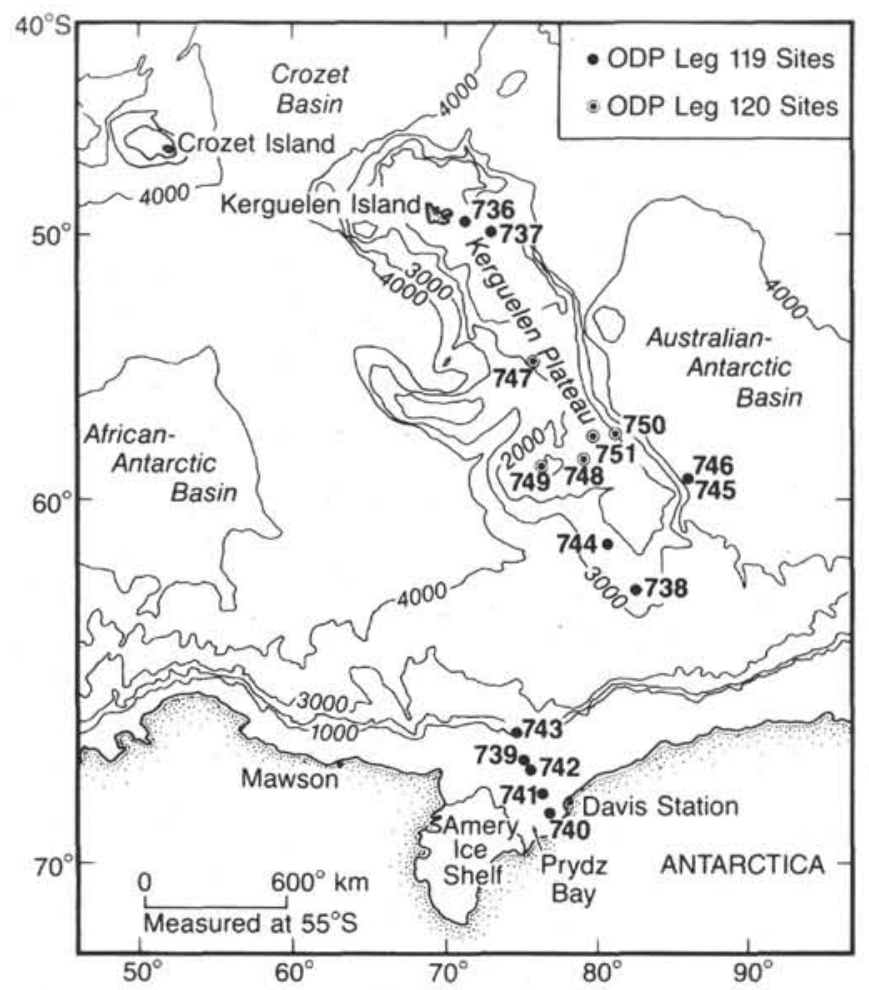

Figure 1. Map showing the locations of Leg 119 and 120 sites on Kerguelen Plateau.

1988). Paleontological and stable isotope studies of this sequence revealed a pattern of rapid extinction of planktonic micro fauna and flora and a near complete collapse of carbon isotope gradients, similar to that recorded at low latitudes (Stott and Kennett, 1989). A return to normal vertical carbon isotope gradients and carbonate accumulation rates in the early Danian, however, occurred $0.2 \mathrm{~m} . \mathrm{y}$. earlier than recorded at lower latitude sequences. The apparent temporal offset of post-boundary carbon isotope events indicates that either (1) environmental parameters played an important role in moderating the post-boundary evolution of biota and marine ecosystems, or (2) the $\mathrm{K} / \mathrm{P}$ carbon isotope record may not represent changes in the distribution of carbon isotopes in paleo-seawater but is more representative of differences in vital effects between extinct Cretaceous and new Danian plankton species (e.g., Stott and Kennett, 1989, 1990a). Alternatively, the apparent temporal discrepancy may simply be an artifact of stratigraphic problems (Pospichal and Wise, 1990).

To constrain the high-latitude recovery rate of the marine biosphere following the K/P boundary event, we conducted an integrated paleontological, magnetic, sedimentological, and geochemical investigation of samples taken from across the $\mathrm{K} / \mathrm{P}$ boundary at Site 750 . Although the uppermost Cretaceous and lowermost Danian are absent, a continuous NP1-NP2 zonal interval is present, permitting a detailed reconstruction of the post-boundary evolution of biota and surface-water fertility at high latitudes. This report describes the findings of our integrated investigation.

\section{METHODS}

\section{Stable Isotopes}

Sampling for stable isotope analyses was conducted at $5-10-\mathrm{cm}$ intervals in the section containing the $\mathrm{K} / \mathrm{P}$ boundary
(120-750A-15R-3) and at 20-30-cm intervals in the sections above and below (120-750A-15R-3 and -2 , and 120-750A-16R1). Bulk samples were freeze dried and split. One half of each sample was disaggregated in a warm $\left(50^{\circ} \mathrm{C}\right)$ sodium metaphosphate solution and wet-sieved through $63-\mu \mathrm{m}$ mesh sieves. The remaining half of each sample was finely ground by mortar and pestle. Planktonic and benthic foraminifers were hand picked from the $>150-\mu \mathrm{m}$ fraction for stable isotopic analyses. Individual foraminifer samples were sonicated in methyl alcohol to remove adhering particles.

In final preparation for stable isotope analyses, 0.02-0.08 mg samples were roasted under vacuum at $380^{\circ} \mathrm{C}$ for $1 \mathrm{hr}$. Samples were loaded into an automated carbonate preparation Kiel device in which the samples were reacted in phosphoric acid at $75^{\circ} \mathrm{C}$. The resulting $\mathrm{CO}_{2}$ was purified in a single-step distillation process and transferred to a Finnegan MAT-251 mass spectrometer for measurement. All stable isotope values are reported in the delta notation $(\delta)$ relative to PDB, using the following equation:

$$
\delta(\%)=[(\text { R Samp. } / \text { R Stand. })-1] \times 10^{3} .
$$

Isotopic values were corrected for ${ }^{17} \mathrm{O}$ interference according to the equations of Craig (1957). Analytical precision based on replicate analyses of NBS-20 was better than $0.1 \%$ or both carbon and oxygen isotopes.

Percent carbonate analyses were performed on ground bulk samples using the "Karbonate Bombe" method of Müller and Gastner (1971). Analytical precision based on duplicate analyses was better than $\pm 2 \%$. For more detailed descriptions of the micropaleontology methods and techniques, see individual chapters in this volume (Berggren, this volume; Ehrendorfer and Aubry, this volume).

\section{LITHOLOGY, PALEOMAGNETICS, AND BIOSTRATIGRAPHY}

\section{Lithology}

The K/P boundary sequence was penetrated in Section $120-750 \mathrm{~A}-15 \mathrm{R}-3,91.5 \mathrm{~cm}$, at an approximate sub-bottom depth of $349.50 \mathrm{~m}$. The upper Maestrichtian unit consists of small 10-20 cm clasts or "drill biscuits" of semi-indurated white nannofossil chalk (Subunit IIIA) (Fig. 2). Subunit IIIA is unconformably overlain by a lower Danian grayish green marl (Subunit IIB). The contact between the two units is fractured and discontinuous, suggesting that the unconformity resulted from drilling as the more lithified Danian unit was ground into the somewhat softer Maestrichtian sediments. The grayish green marl gradually grades into a white chalk over a $65-\mathrm{cm}$ interval immediately above the $\mathrm{K} / \mathrm{P}$ boundary.

A rapid change in whole-rock carbonate content was measured across the K/P boundary at Hole $750 \mathrm{~A}$. The carbonate contents of upper Maestrichtian sediment are constant near 95\% (Table 1 and Fig. 2), whereas the carbonate contents of Danian sediment gradually increase from $83 \%$ just above the boundary to $95 \%$ some $70 \mathrm{~cm}$ upsection. The gradual increase in carbonate content corresponds with the green to white color gradation described above.

\section{Magnetostratigraphy and Rock Magnetics}

Although the sediments at Hole $750 \mathrm{~A}$ yielded a detectab'e remanent magnetism, identification of reversal boundarics was difficult because of the poor core recovery. Several normal polarity magnetozones were tentatively identified in the lower Paleocene based on their relative positions to nannofossil zones (Heider et al., this volume). Intervals of 
normal polarity extending from 338 to 342 mbsf and from 319 to 322 mbsf were identified as belonging to Chrons $28 \mathrm{~N}$ and $27 \mathrm{~N}$, respectively; because of the large coring gaps, the upper and lower boundaries of both magnetozones could not be unambiguously constrained.

Magnetic susceptibility measurements were performed on closely spaced samples from across the $\mathrm{K} / \mathrm{P}$ boundary interval in Section 120-750A-15R-3 (Fig. 3). The susceptibility $\mathrm{K}$ values show a sudden increase from the Maestrichtian to the Danian, peaking at $8 \mathrm{~K}$, followed by a rapid decrease to $5.5 \mathrm{~K}$ within $10 \mathrm{~cm}$, and then a gradual decrease to $1 \mathrm{~K}$ at the top of the section. The gradual decrease in $\mathrm{K}$ above the boundary parallels the color gradation and increase in carbonate contents described above. Therefore, the decrease probably reflects variations in the concentrations of ironbearing clays within the sediments. Superimposed on this overall trend in $\mathrm{K}$ may be the effects of magnetite spherules. Magnetite spherules, which carry a high susceptibility, have been observed in $\mathrm{K} / \mathrm{P}$ boundary samples from other pelagic sequences (Worm and Banerjee, 1987). A preliminary search, however, revealed no such spherules at Site 750 . Because susceptibility $\mathbf{K}$ values exhibit a significant negative correlation with carbonate content at this site, the susceptibility record serves as a reasonable proxy of relative variation in carbonate content.

\section{Calcareous Nannofossils}

The Nephrolithus frequens Zone, the uppermost calcareous nannofossil zone in the Maestrichtian, extends from the upper part of Section 120-750A-19R-1 to the K/P boundary in Sample 120-750A-15R-3, $91.5 \mathrm{~cm}$ (350 mbsf) (Watkins, this volume). Although the upper Maestrichtian appears to be well developed at this site, it is possible that some latest Maestrichtian sediment is missing.

The oldest Danian sediments recovered from Hole $750 \mathrm{~A}$ belong to Zone NP1 at a level below but close to the first appearance of Cruciplacolithus primus. Because of poor preservation and also because of the minute size of the first forms of the newly evolved genus Cruciplacolithus, the lowest occurrence of $C$. tenuis was extremely difficult to establish ( $C$. tenuis here is distinguished independently from size by the presence of "feet" at the contact between the central cross and the margin, and by a small central area relative to the diameter of the placolith compared with $C$. primus). Scanning electron microscope (SEM) observations proved to be time consuming and ineffective because of recrystallization, high fragmentation, and the presence of numerous loose fragments obscuring the central area of most placoliths. Cruciplacolithus tenuis is common in Core 120$750 \mathrm{~A}-14 \mathrm{R}$, but very rare in Core $120-750 \mathrm{~A}-15 \mathrm{R}$, and its occurrence was eventually established through the use of a gypsum plate. The lowest occurrence of $C$. tenuis seems to be in Sample 120-750A-15R-3, 51-52 cm, and the NP1/NP2 zonal boundary was drawn between Samples 120-750A$15 \mathrm{R}-3,60-61$ and $50-51 \mathrm{~cm}$. It is possible, however, that the actual first appearance of $C$. tenuis was lower at Sample 120-750A-15R-3, $86 \mathrm{~cm}$, where the first Cruciplacolithus occur, but because of poor preservation were indistinguishable. The NP2/NP3 zonal boundary was placed near the top of Core 120-750A-15R between Samples 120-750A-15R-1, 34 $\mathrm{cm}$, and $-15 \mathrm{R}-1,100 \mathrm{~cm}$.

A detailed record of changes in calcareous nannofossil assemblage compositions across the $\mathrm{K} / \mathrm{P}$ boundary was established through counts of the relative abundance of taxa (Fig. 4) (Ehrendorfer and Aubry, this volume). The Maestrichtian assemblages are dominated by vanishing taxa, forms which apparently have no direct descendants in the Paleocene and

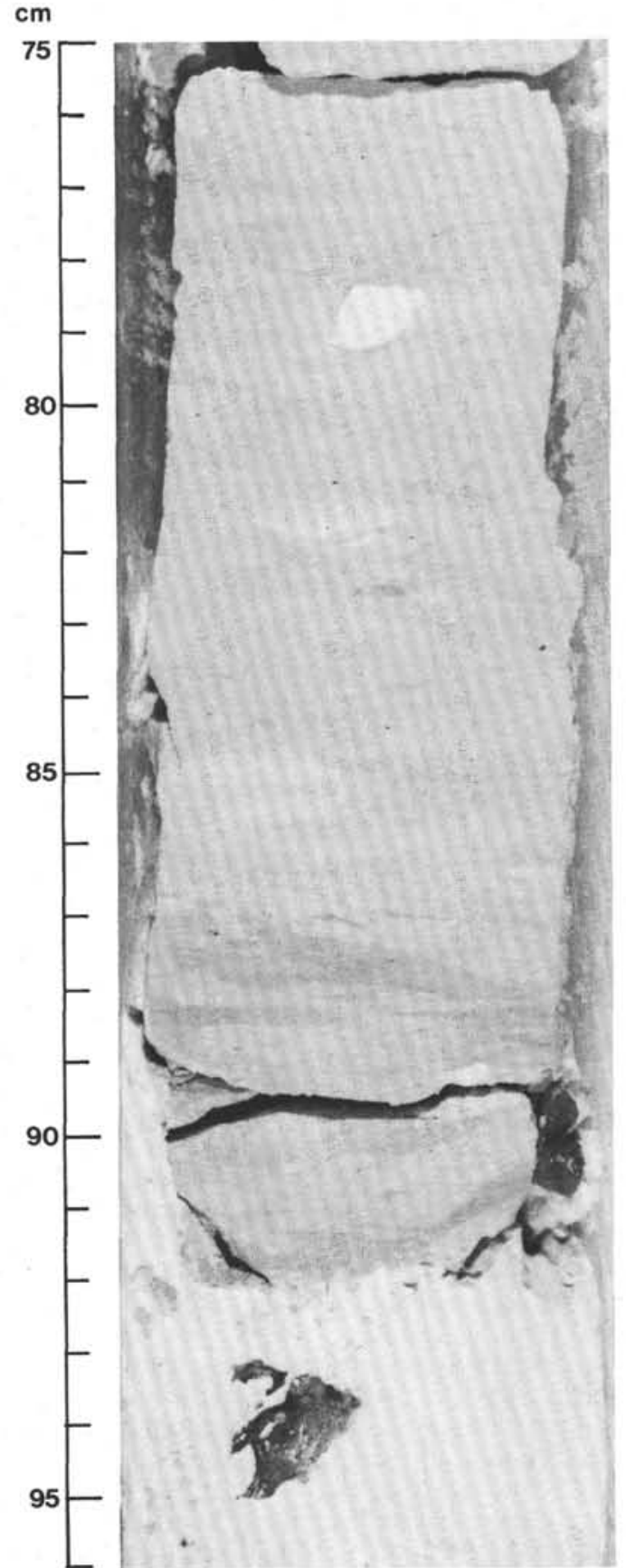

Figure 2. Photograph of the Cretaceous/Paleocene $(\mathrm{K} / \mathrm{P})$ boundary in Section $120-750 \mathrm{~A}-15 \mathrm{R}-3$ at $90 \mathrm{~cm}$.

are often assumed to be reworked in the lowest Paleocene sediments. The persistent taxa, mainly Placozygus fibuliformis, constitute $<5 \%$ of the Maestrichtian assemblages and, in the few samples examined, seem to show little change in composition just before the boundary.

The earliest Danian calcareous nannofossil assemblages recovered from Hole $750 \mathrm{~A}$ partly consist of species of the persistent genera, mainly Placozygus sigmoides and fragments of the dinoflagellates Thoracosphaera spp. The remaining taxa (about $10 \%$ of the assemblages) are representatives of the incoming genera and reworked species of the vanishing genera. The relative abundance of persistent taxa decreases rapidly from $90 \%$ to $15 \%$ within $50 \mathrm{~cm}$ above the 
Table 1. Whole-rock $\% \mathrm{CaCO}_{3}$ data, Hole 750A.

\begin{tabular}{lll}
\hline $\begin{array}{c}\text { Core, section, } \\
\text { interval (cm) }\end{array}$ & $\begin{array}{l}\text { Depth } \\
\text { (mbsf) }\end{array}$ & $\mathrm{CaCO}_{3}(\%)$ \\
\hline 120-750A- & & \\
15R-2, 8-12 & 347.68 & 94.09 \\
15R-2, 28-32 & 347.88 & 97.21 \\
15R-2, 88-72 & 348.28 & 98.57 \\
15R-2, 128-132 & 348.88 & 94.58 \\
15R-3, 2-4 & 349.12 & 96.28 \\
15R-3, 36-38 & 349.46 & 92.77 \\
15R-3, 49-51 & 349.59 & 88.34 \\
15R-3, 56-58 & 349.66 & 87.90 \\
15R-3, 63-65 & 349.73 & 89.20 \\
15R-3, 70-72 & 349.80 & 86.62 \\
15R-3, 77-79 & 349.87 & 68.06 \\
15R-3, 83-85 & 349.93 & 68.20 \\
15R-3, 88-90 & 349.98 & 83.03 \\
15R-3, 101-102 & 350.11 & 95.97 \\
15R-3, 104-106 & 350.14 & 93.34 \\
15R-3, 110-112 & 350.20 & 98.85 \\
15R-3, 115-117 & 350.25 & 97.83 \\
16R-1, 26-30 & 356.06 & 94.00 \\
16R-1, 48-52 & 356.28 & 96.14 \\
\hline
\end{tabular}

boundary, whereas the relative abundance of incoming taxa increases. The relative abundance of persistent taxa increases further upsection in Zone NP2, at which point they reach $20 \%$ at $348.60 \mathrm{mbsf}$, then decline to $<5 \%$ at 347.50 mbsf. Prinsius tenuiculum is the most abundant of the incoming taxa, with relative abundances exceeding $80 \%$ of the total assemblages. It is uncertain whether sharp variations in the abundance of $P$. tenuiculum in Core 120-750A$15 \mathrm{R}$ reflect variations in preservation or genuine variations in production.

Relative abundance counts of species in lower Danian assemblages from Hole $750 \mathrm{~A}$ indicate that the abundances of incoming taxa and of persistent taxa are inversely proportional, so that by the time the former become fully established the latter have nearly disappeared. To confirm this apparent relationship between persistent and incoming taxa made by relative counts, measures of absolute abundance were performed on selected samples prepared according to the settling method described by Beaufort (in press). The results are shown in Table 2 and Figures $5 \mathrm{~A}$ and $5 \mathrm{~B}$. The absolute abundance of the vanishing taxa decreases sharply above 349.61 mbsf. Although there is a general reduction in absolute abundance of the persistent taxa between 350 and 347.50 mbsf, there is no sharp decrease in this interval, except for a minor one between 349.66 and 349.61 mbsf. The reduction in abundance occurs gradually, unlike the sharper decrease in relative abundance between 350 and 349.10 mbsf. There is a parallel but more pronounced decrease in absolute abundance of Thoracosphaera spp., forms often regarded as opportunistic (e.g., Thierstein, 1981). Although a steady increase in the abundance of the placoliths of Cruciplacolithus was observed throughout the section, more impressive is the increase in absolute abundance of Prinsius tenuiculum. The two instances of lower abundances between 349.66 and 349.46 mbsf and between 349.36 and 348.15 mbsf are unexplained at this time. Furthermore, the sharp increase in abundance between 349.44 and 347.50 is prominent.

\section{Planktonic Foraminifers}

Faunas below Sample 120-750A-15R-3, $92 \mathrm{~cm}$ (K/P boundary, 350 mbsf), consist of latest Maestrichtian Abathomphalus mayaroensis Zone assemblages characterized by Globigerinelloides messinae, G. subcarinata, Hedbergella monmouthensis, Rugoglobigerina macrocephala, $R$. pustulata, and $R$. rugosa in addition to the nominate form of the zone and various heterohelicids (Fig. 6). The A. mayaroensis Zone extends from $350 \mathrm{mbsf}$ downsection to $384.7 \mathrm{mbsf}$.

Samples from above $120-750 \mathrm{~A}-15 \mathrm{R}-3,88-90 \mathrm{~cm}$, to $-15 \mathrm{R}-2$, 88-92 cm (i.e., 0-1.5 m above the Maestrichtian/Paleocene boundary), consist of eoglobigerinids, subbotinids, globoconusids, and various triserial and biseral heterohelicids (Chiloguembelina, Woodringina, Guembelitria, among others) (Fig. 6). The lowest sample examined above the boundary (120750 A-15R-3, $88-90 \mathrm{~cm}$ ) does not contain Parvularugoglobigerina eugubina, but it does contain Eoglobigerina eobulloides, Subbotina trivialis, Globanomalina archaeocompressa, Guembelitria cretacea, Chiloguembelina morsei, as well as several forms from the Upper Cretaceous (Globigerinelloides messinae and $H$. monmouthensis). Individuals of the upper Maestrichtian species $G$. messinae and $H$. globulosa continue up to Sample 120-750A-15R-3, 63-65 cm (i.e., about $25-30 \mathrm{~cm}$ above the boundary). Woodringina honerstownensis and $W$. claytonensis appear about $30-40 \mathrm{~cm}$ above the boundary and Paragloborotalia pseudobulloides and Globoconusa daubjergensis appear about $20-25 \mathrm{~cm}$ above the boundary. The presence of Paragloborotalia taurica and P. pseudobulloides at Sample 120$750 \mathrm{~A}-15 \mathrm{R}-3,77-79 \mathrm{~cm}$ (some $25 \mathrm{~cm}$ above the boundary), indicates the presence of Zone Pla at this level. Thus, the lowermost 20-25 cm with eoglobigerinids above the Maestrichtian/Paleocene boundary is assigned to Zones P $\alpha-P 1 a$ (Smit, 1982) undifferentiated.

\section{Stable Isotopes}

To reconstruct late Maestrichtian and early Danian surface- to deep-water carbon isotope gradients, stable isotope analyses were performed on benthic foraminifers Stensioina beccariiformis and Nuttallides truempyi and planktonic foraminifers Heterohelix globulosa, Eoglobigerina eobulloides, and Globigerinelloides spp. To build a more continuous time series, analyses were also conducted on bulk- and finefraction $(<63-\mu \mathrm{m})$ samples. Although some foraminifers from each sample were dissolved and/or overgrown with calcite cements, others were free of foreign material. The degree of cementation corresponded to sediment lithification and thus appears to be an artifact of burial diagenesis (these samples were recovered from a burial depth of $>350 \mathrm{mbsf}$ close to the chalk-limestone transition depth for pelagic carbonate sediments (Schlanger and Douglas, 1974). Although the measured oxygen isotope ratios appear to be close to those expected at this high latitude, diagenesis has probably modified the primary oxygen isotope compositions of the carbonate to some unknown degree (e.g., Killingley, 1983). As a result, the oxygen isotope data are reported, but they will not be discussed in detail. In contrast, the effects of burial diagenesis on microfossil carbonate $\delta^{13} \mathrm{C}$ in sediments with low initial organic carbon content tend to be small as most of the carbon in the pelagic sediment/porewater system is located in biogenic carbonate phases (Arthur et al., 1989).

Upper Maestrichtian bulk samples from Sections 120 $750 \mathrm{~A}-16 \mathrm{R}-1$ and $-15 \mathrm{R}-3$ yielded mean $\delta^{13} \mathrm{C}$ values of 2.1 (Table 3 and Fig. 7C). Benthic foraminifers $S$. beccariiformis and $N$. truempyi yielded lower values from $1.1 \%$ to $1.15 \%$. Bulk $\delta^{13} \mathrm{C}$ values decreased across the $\mathrm{K} / \mathrm{P}$ boundary by $1.0 \%$, whereas benthic foraminifer $\delta^{13} \mathrm{C}$ values remain constant. As a result, the earliest Danian bulk samples and benthic foraminifer values overlap and fall between $1.1 \%$ to $1.3 \%$. The values remain homogeneous until $40 \mathrm{~cm}$ above the boundary or at 349.6 mbsf at which level the bulk and planktonic foraminifer $\delta^{13} \mathrm{C}$ values begin to increase. By $349.1 \mathrm{mbsf}$, within the lower part of the NP2 Zone, the bulk $\delta^{13} \mathrm{C}$ values increase to $2.4 \%$, as benthic values remain constant. 


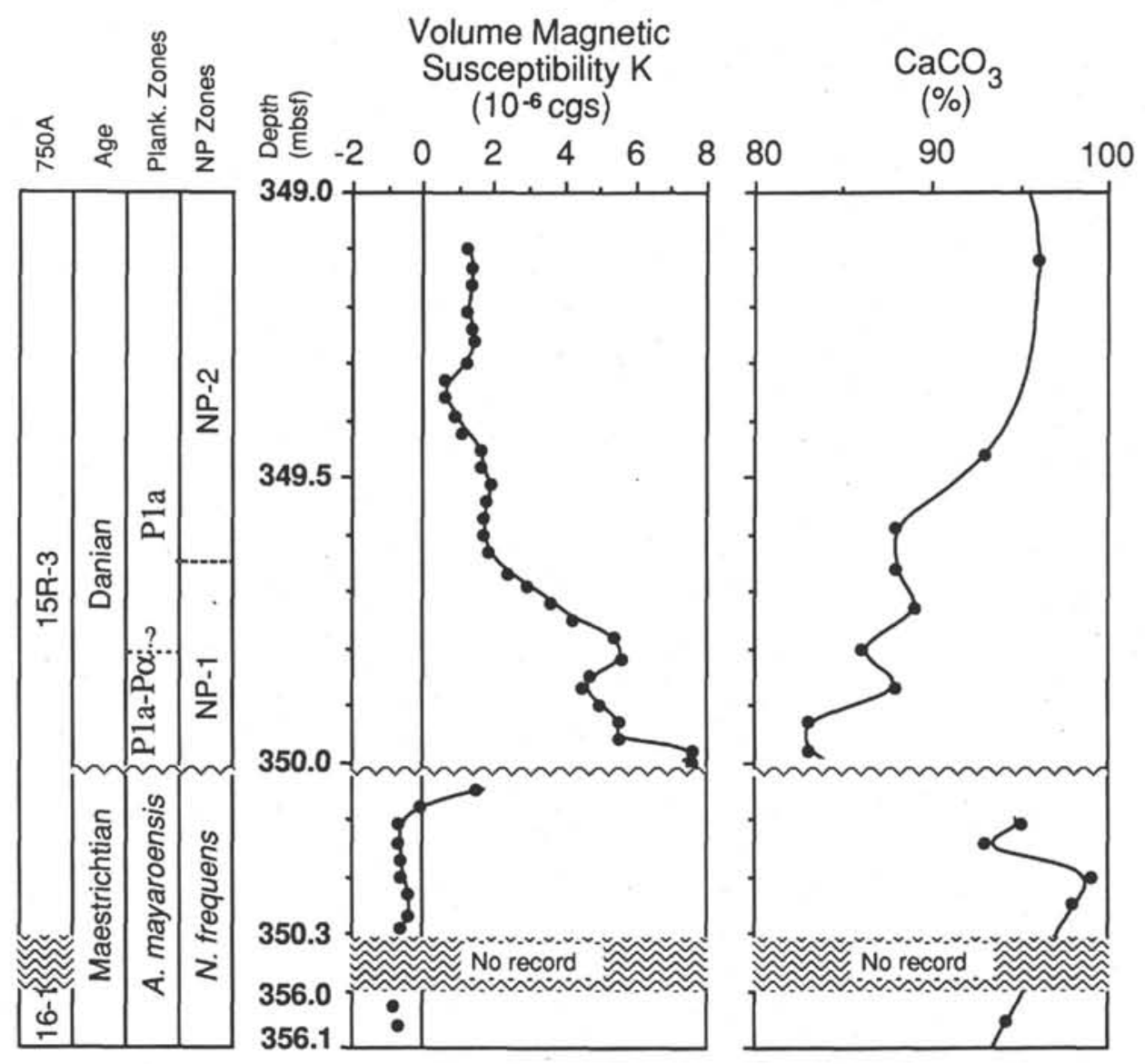

Figure 3. Whole-rock magnetic susceptibility $\mathrm{K}$ values and carbonate contents across the $\mathrm{K} / \mathrm{P}$ boundary at Site 750 .

Because the bulk and fine fractions of pelagic sediments are predominantly composed of coccoliths, their $\delta^{13} \mathrm{C}$ signals should be approximately representative of mixed layer total dissolved carbon (TDC) $\delta^{13} \mathrm{C}$ compositions (e.g., Goodney et al., 1980; Dudley et al., 1986). This assumption was tested true in several Cretaceous and Paleogene pelagic sequences for which bulk or fine fraction samples and individual species of planktonic foraminifers were analyzed (Shackleton et al., 1984; Zachos et al., 1989). A potential pitfall in using bulk samples is seafloor dissolution, which, by removing solution-susceptible species, may sufficiently alter the character of nannofossil assemblages and shift the carbon or oxygen isotopic compositions of the bulk sample by several tenths of per mil (Paull and Thierstein, 1987; Paull et al., 1988). To guard against this potential artifact, the bulk and fine fraction samples at Site 750 were calibrated in random samples to individual species of planktonic foraminifers. In upper Maestrichtian sediments, $\boldsymbol{H}$. globulosa and Globigerinelloides yielded $\delta^{13} \mathrm{C}$ values that bracket whole-rock values and in lower Danian samples $E$. eobulloides yielded $\delta^{13} \mathrm{C}$ values that are $0.3 \%$ o higher than whole-rock values (Figs. 7 and 8 ).

To test whether the upper Cretaceous foraminifers $H$. globulosa and Globigerinelloides present in lower Danian samples were reworked, specimens from five samples in a $30-\mathrm{cm}$ interval above the $\mathrm{K} / \mathrm{P}$ boundary were analyzed. The mean $\delta^{13} \mathrm{C}$ value for H. globulosa was 1.85 and for Globigerinelloides 2.2, both significantly higher than whole-rock and Danian planktonic foraminifer compositions. In fact, specimens of $\boldsymbol{H}$. globulosa show essentially no change from the upper Maestrichtian samples, indicating that these specimens are most likely reworked (Fig. 7).

\section{Duration of the Hiatus at the $\mathrm{K} / \mathrm{P}$ Unconformity at Hole 750A}

In the $\mathrm{K} / \mathrm{P}$ boundary biozonation of Berggren and Miller (1988), the earliest Danian planktonic foraminifer zone is designated $\mathrm{P} \alpha$, a zone typically identified by the presence of Eoglobigerina eobulloides and $E$. fringa and the absence of $P$. pseudobulloides, whereas the overlying Zone P1a is characterized by the co-occurrence of $P$. pseudobulloides and $G$. daubjergensis. The presence of fauna representative of the P1a and $\mathrm{P} \alpha$ zones at Site 750 imply that less than 300 k.y. of the early Danian is missing (Fig. 6). The lowermost Danian nannofossil Zone NP1 (CP1a) is represented by a 10-40-cm interval above the boundary, and below the first appearance of $C$. tenuis. Within Zone NP1 is a $10-\mathrm{cm}$ interval in which Cruciplacolithus are absent. In standard zonations the lower portion of the lowermost Danian nannofossil Zone NP1 is characterized by a lack of Cruciplacolithus (the first appearance datum [FAD] of $C$. primus, the precursor of $C$. tenuis, normally occurs within Zone NP1). The absence of Cruciplacolithus in the lower $10 \mathrm{~cm}$ indicates that at least a portion of the lower NP1 Zone is present at Site 750.

Standard upper Maestrichtian biozones tend to be lengthy (the $N$. frequens and $A$. mayaroensis zones extend from 66.5 to 68.75 and $69.1 \mathrm{Ma}$, respectively [Kent and Gradstein, 1985]), so that it is more difficult to estimate the thickness, if any, of upper Maestrichtian sediment that is absent at Site 750. The A. mayaroensis Zone at Site 750 is $38 \mathrm{~m}$ thick, yielding a sedimentation rate of $6 \mathrm{~m} / \mathrm{m}$.y., so it is evident that most of the upper Maestrichtian is present. Thus, based 


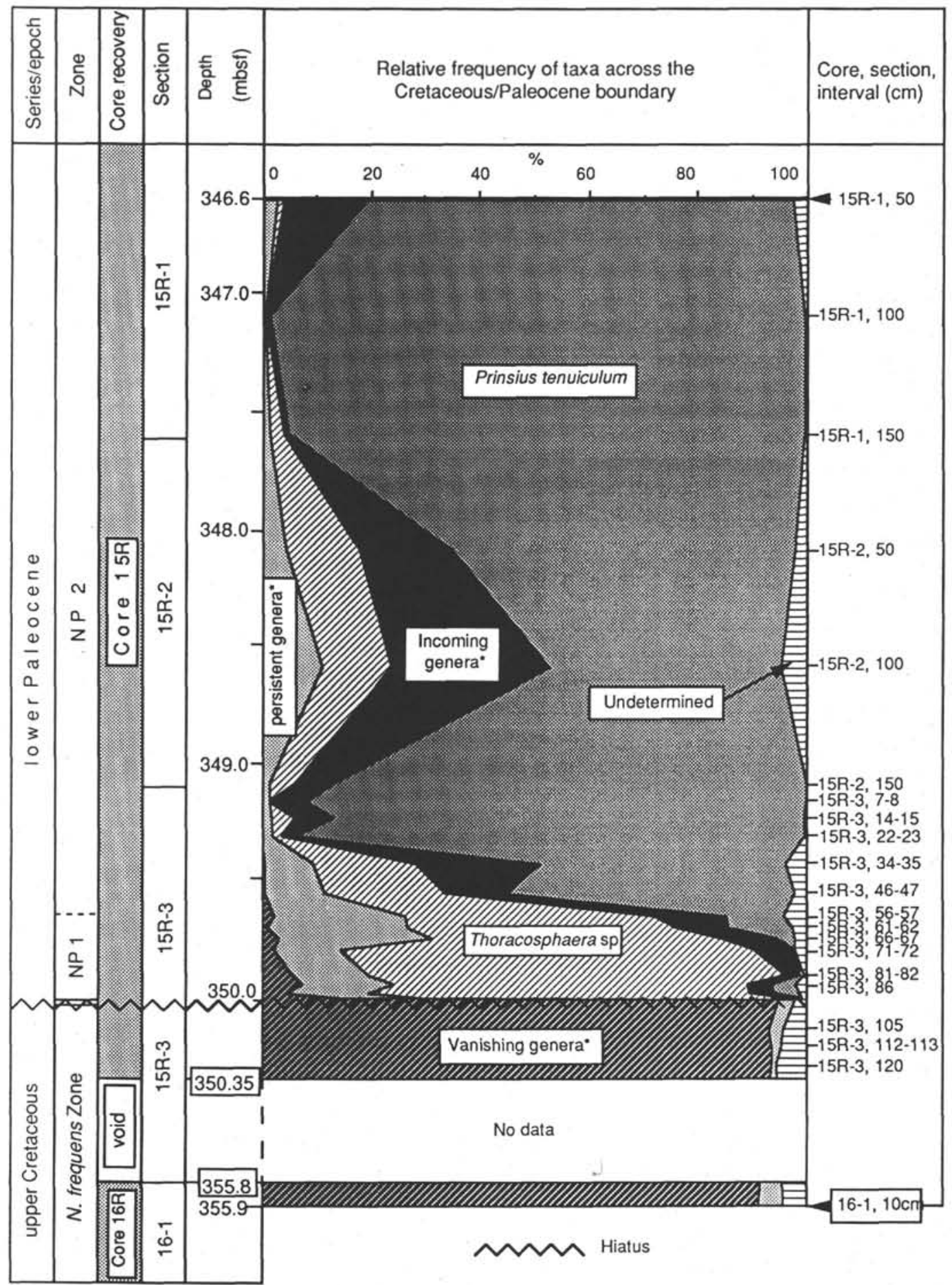

Figure 4. Relative abundances of nannoplankton taxa vs. depth (mbsf) across the K/P boundary at Site 750 (Ehrendorfer and Aubry, this volume).

on the above information, it appears that the $\mathrm{K} / \mathrm{P}$ hiatus at Site 750 may not be longer than 300 k.y.

\section{DISCUSSION}

Previous investigations of deep-sea sequences demonstrated that the extinction of marine planktonic fauna and flora at the $\mathrm{K} / \mathrm{P}$ boundary was accompanied by a substantial decrease in the rate of global oceanic primary productivity (e.g., Hsü et al., 1982a, 1982b; Shackleton et al., 1984; Zachos and Arthur, 1986). Characteristic of the decrease in productivity were blooms of "opportunistic" species of nannoplankton, lowered biogenic carbonate accumulation rates, and reduced surface- to deep-water and basin-to-basin carbon isotope gradients. Surface to deep $\delta^{13} \mathrm{C}$ gradients are normally sustained by rapid flux of ${ }^{12} \mathrm{C}$-enriched organic carbon from the photic zone to deeper waters (biological pumping; e.g., Kroopnick, 1985); thus, the absence of such gradients indicates that flux of organic carbon to the deep ocean declined. Eventual 
Table 2. Relative and absolute abundances of nannofossils from the lower Danian, Hole 750A.

\begin{tabular}{|c|c|c|c|c|c|c|c|c|c|c|c|c|c|c|c|c|c|c|}
\hline \multirow{2}{*}{$\begin{array}{l}\text { Core, section, } \\
\text { interval }(\mathrm{cm})\end{array}$} & \multirow{2}{*}{$\begin{array}{l}\text { Depth } \\
\text { (mbsf) }\end{array}$} & \multirow[b]{2}{*}{1} & \multirow[b]{2}{*}{2} & \multirow[b]{2}{*}{3} & \multirow[b]{2}{*}{4} & \multirow[b]{2}{*}{5} & \multirow[b]{2}{*}{6} & \multirow[b]{2}{*}{ Field } & \multirow[b]{2}{*}{7} & \multirow[b]{2}{*}{ Field } & \multirow[b]{2}{*}{ Weight } & \multicolumn{7}{|c|}{ Absolute abundances } \\
\hline & & & & & & & & & & & & 1 & 2 & 3 & 4 & 5 & 6 & 7 \\
\hline \multicolumn{19}{|l|}{$120-750 \mathrm{~A}-$} \\
\hline $15 \mathrm{R}-3,85-86$ & 349.95 & 12 & 55 & 86 & 10 & 2 & 2 & 16 & 159 & 16 & 16.50 & $1.83 \mathrm{E}+02$ & $8.40 \mathrm{E}+02$ & $1.31 \mathrm{E}+03$ & $1.53 \mathrm{E}+02$ & $3.05 \mathrm{E}+01$ & $3.05 \mathrm{E}+01$ & $2.43 \mathrm{E}+03$ \\
\hline $15 \mathrm{R}-3,81-82$ & 349.91 & 20 & 49 & 89 & 8 & 0 & 0 & 13 & 130 & 13 & 22.50 & $2.76 \mathrm{E}+02$ & $6.75 E+02$ & $1.23 E+03$ & $1.10 \mathrm{E}+02$ & $0.00 \mathrm{E}+00$ & $0.00 \mathrm{E}+00$ & $1.79 \mathrm{E}+03$ \\
\hline $15 \mathrm{R}-3,76-77$ & 349.86 & 15 & 54 & 95 & 11 & 13 & 0 & 12 & 219 & 12 & 22.50 & $2.24 \mathrm{E}+02$ & $8.06 \mathrm{E}+02$ & $1.42 \mathrm{E}+03$ & $1.64 \mathrm{E}+02$ & $1.94 \mathrm{E}+02$ & $0.00 \mathrm{E}+00$ & $3.27 \mathrm{E}+03$ \\
\hline $15 \mathrm{R}-3,66-67$ & 349.76 & 16 & 77 & 81 & 11 & 9 & 0 & 12 & 230 & 5 & 22.20 & $2.42 \mathrm{E}+02$ & $1.17 \mathrm{E}+03$ & $1.23 \mathrm{E}+03$ & $1.66 \mathrm{E}+02$ & $1.36 \mathrm{E}+02$ & $0.00 \mathrm{E}+00$ & $8.35 \mathrm{E}+03$ \\
\hline $15 R-3,56-57$ & 349.66 & 13 & 103 & 72 & 11 & 34 & 2 & 20 & 252 & 7 & 18.00 & $1.46 \mathrm{E}+02$ & $1.15 \mathrm{E}+03$ & $8.06 \mathrm{E}+02$ & $1.23 \mathrm{E}+02$ & $3.81 \mathrm{E}+02$ & $2.24 \mathrm{E}+01$ & $8.06 \mathrm{E}+03$ \\
\hline $15 \mathrm{R}-3,51-52$ & 349.61 & 3 & 102 & 81 & 12 & 55 & 0 & 20 & 278 & 11 & 28.80 & $2.10 \mathrm{E}+01$ & $7.14 \mathrm{E}+02$ & $5.67 \mathrm{E}+02$ & $8.40 \mathrm{E}+01$ & $3.85 \mathrm{E}+02$ & $0.00 \mathrm{E}+00$ & $3.54 \mathrm{E}+03$ \\
\hline $15 \mathrm{R}-3,46-47$ & 349.56 & 6 & 98 & 146 & 11 & 55 & 0 & 20 & 229 & 12 & 25.50 & $4.74 \mathrm{E}+01$ & $7.75 E+02$ & $1.15 \mathrm{E}+03$ & $8.69 \mathrm{E}+01$ & $4.35 \mathrm{E}+02$ & $0.00 \mathrm{E}+00$ & $3.02 \mathrm{E}+03$ \\
\hline $15 \mathrm{R}-3,36-37$ & 349.46 & 7 & 91 & 127 & 9 & 99 & 1 & 20 & 288 & 6 & 29.70 & $4.75 \mathrm{E}+01$ & $6.17 \mathrm{E}+02$ & $8.62 \mathrm{E}+02$ & $6.11 \mathrm{E}+01$ & $6.72 \mathrm{E}+02$ & $6.79 \mathrm{E}+00$ & $6.51 \mathrm{E}+03$ \\
\hline $15 \mathrm{R}-3,34-35$ & 349.44 & 4 & 90 & 91 & 5 & 145 & 0 & 20 & 415 & 2 & 31.30 & $2.58 \mathrm{E}+01$ & $5.79 \mathrm{E}+02$ & $5.86 \mathrm{E}+02$ & $3.22 \mathrm{E}+01$ & $9.34 \mathrm{E}+02$ & $0.00 \mathrm{E}+00$ & $2.67 \mathrm{E}+04$ \\
\hline $15 \mathrm{R}-3,26-27$ & 349.36 & 10 & 104 & 86 & 3 & 145 & 0 & 20 & 467 & 3 & 36.40 & $5.54 \mathrm{E}+01$ & $5.76 \mathrm{E}+02$ & $4.76 \mathrm{E}+02$ & $1.66 \mathrm{E}+01$ & $8.03 E+02$ & $0.00 \mathrm{E}+00$ & $1.72 \mathrm{E}+04$ \\
\hline $15 \mathrm{R}-3,22-23$ & 349.32 & 11 & 85 & 67 & 1 & 151 & 0 & 20 & 579 & 3 & 29.00 & $7.64 \mathrm{E}+01$ & $5.91 \mathrm{E}+02$ & $4.66 \mathrm{E}+02$ & $6.95 \mathrm{E}+00$ & $1.05 \mathrm{E}+03$ & $0.00 \mathrm{E}+00$ & $2.68 \mathrm{E}+04$ \\
\hline $15 \mathrm{R}-3,7-8$ & 349.17 & 3 & 48 & 46 & 6 & 166 & 8 & 20 & 303 & 1 & 35.60 & $1.70 \mathrm{E}+01$ & $2.72 \mathrm{E}+02$ & $2.60 \mathrm{E}+02$ & $3.40 \mathrm{E}+01$ & $9.40 \mathrm{E}+02$ & $4.53 \mathrm{E}+01$ & $3.43 \mathrm{E}+04$ \\
\hline $15 \mathrm{R}-2,95-96$ & 348.55 & 1 & 45 & 43 & 8 & 117 & 13 & 20 & 273 & 4 & 22.70 & $8.88 \mathrm{E}+00$ & $4.00 \mathrm{E}+02$ & $3.82 \mathrm{E}+02$ & $7.10 \mathrm{E}+01$ & $1.04 \mathrm{E}+03$ & $1.15 \mathrm{E}+02$ & $1.21 \mathrm{E}+04$ \\
\hline $15 \mathrm{R}-1,140$ & 347.50 & 4 & 61 & 49 & 4 & 22 & 4 & 40 & 335 & 2 & 23.60 & $1.71 \mathrm{E}+01$ & $2.60 \mathrm{E}+02$ & $2.09 \mathrm{E}+02$ & $1.71 \mathrm{E}+01$ & $9.39 \mathrm{E}+01$ & $1.71 \mathrm{E}+01$ & $2.86 \mathrm{E}+04$ \\
\hline
\end{tabular}

Notes: 1 = vanishing, $2=$ persistent, $3=$ Thoracosphaera, $4=$ Hormbrookina, $5=$ Cruciplacolithus, $6=$ other, inc., and $7=$ Prinsius. 


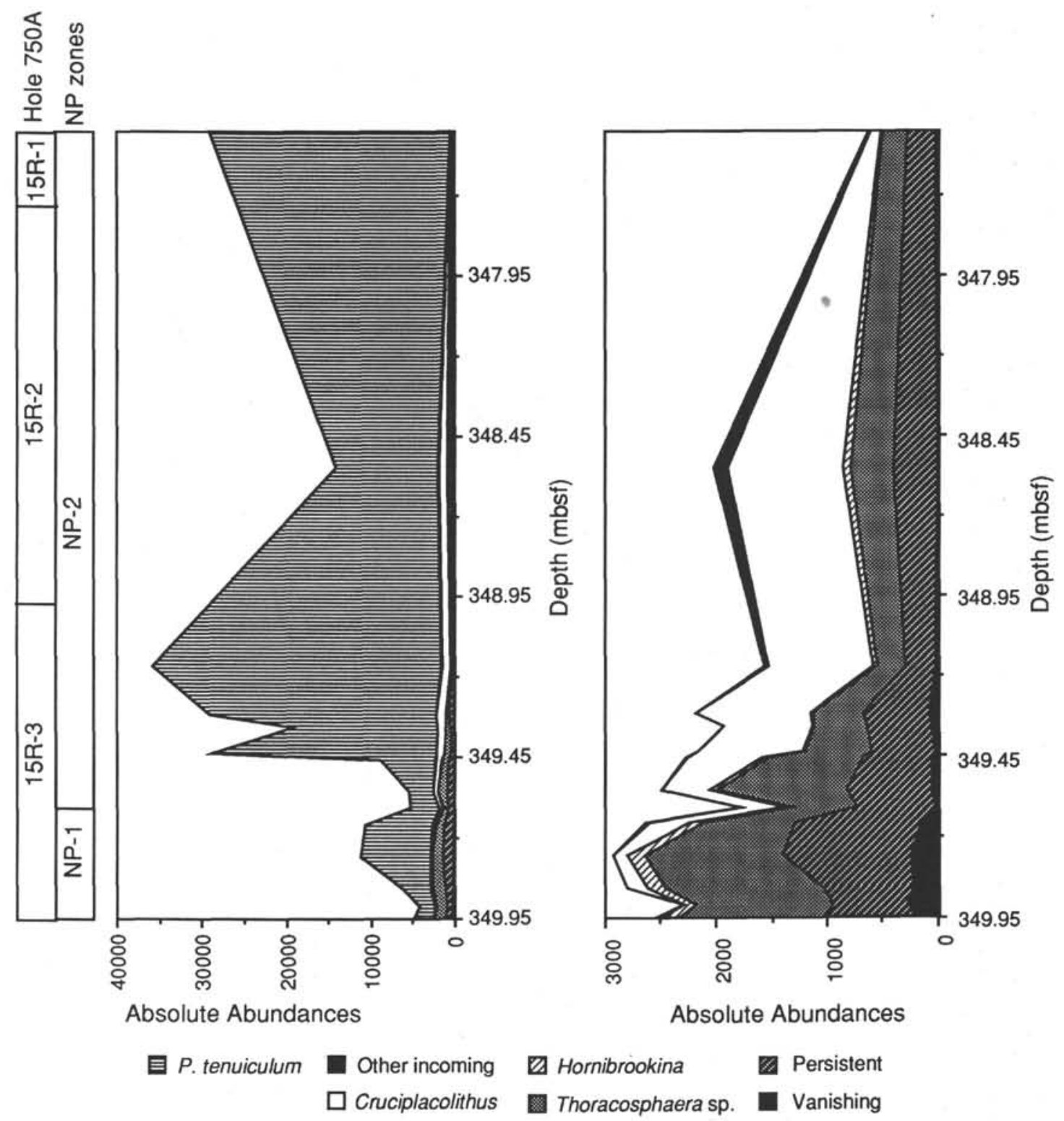

Figure 5. Absolute abundances of nannoplankton taxa vs. depth just above the K/P boundary.

recovery to higher productivity appears to have occurred 0.5 m.y. after the $\mathrm{K} / \mathrm{P}$ boundary when carbon isotope records from low- and mid-latitude Pacific and Atlantic ocean sites returned to normal within Chron 29N, near the NP-1 and NP-2 zonal boundary (Fig. 6; Shackleton and Hall, 1984; Zachos et al., 1989). The high degree of correlation implied that the postboundary carbon isotope events were ubiquitous and therefore must represent changes in global organic carbon fluxes influenced by the long-term recovery of the marine ecosystem.

The lower Danian NP1/NP2 transition interval at Site 750 is marked by changes in fossil assemblages, lithology, and geochemistry, which signify substantial regional paleoecological change of the surface ocean. First, the opportunistic nannofossils that thrived in the post-extinction oceans were replaced by newly evolving forms of calcareous nannofossils, such as Prinsius tenuiculum. This is typical of patterns observed at most other K/P boundary (e.g., Thierstein, 1981; Perch-Nielsen et al., 1982; Manivit and Feinberg, 1984; Monechi, 1985).
Second, a gradual increase in carbonate content occurred at the NP1/NP2 boundary and probably represents an increase in biogenic calcite production and accumulation rates (Fig. 3). Although the calculated carbonate accumulation rates display only a minor increase across this interval (Fig. 9), the actual increase may have been more extreme. At Site 750 , in calculating accumulation rates, it was necessary to use a uniform sedimentation rate for the lower Danian because of the unconformity, an approach which conceals any short-term changes in carbonate accumulation rates. On the basis of a coeval increase in carbonate content and color gradation of early Danian sediments at Site 750, however, it is apparent that carbonate sedimentation rates were significantly lower in the NP1 and lower NP2 Zones than in lower and overlying zones. This intuitive assessment of Site 750 carbonate accumulation rate changes is consistent with recent findings of an expanded and complete Indian Ocean $\mathrm{K} / \mathrm{P}$ boundary sequence at Site 752 on Broken Ridge (Rea et al., 1990). There the K/P 


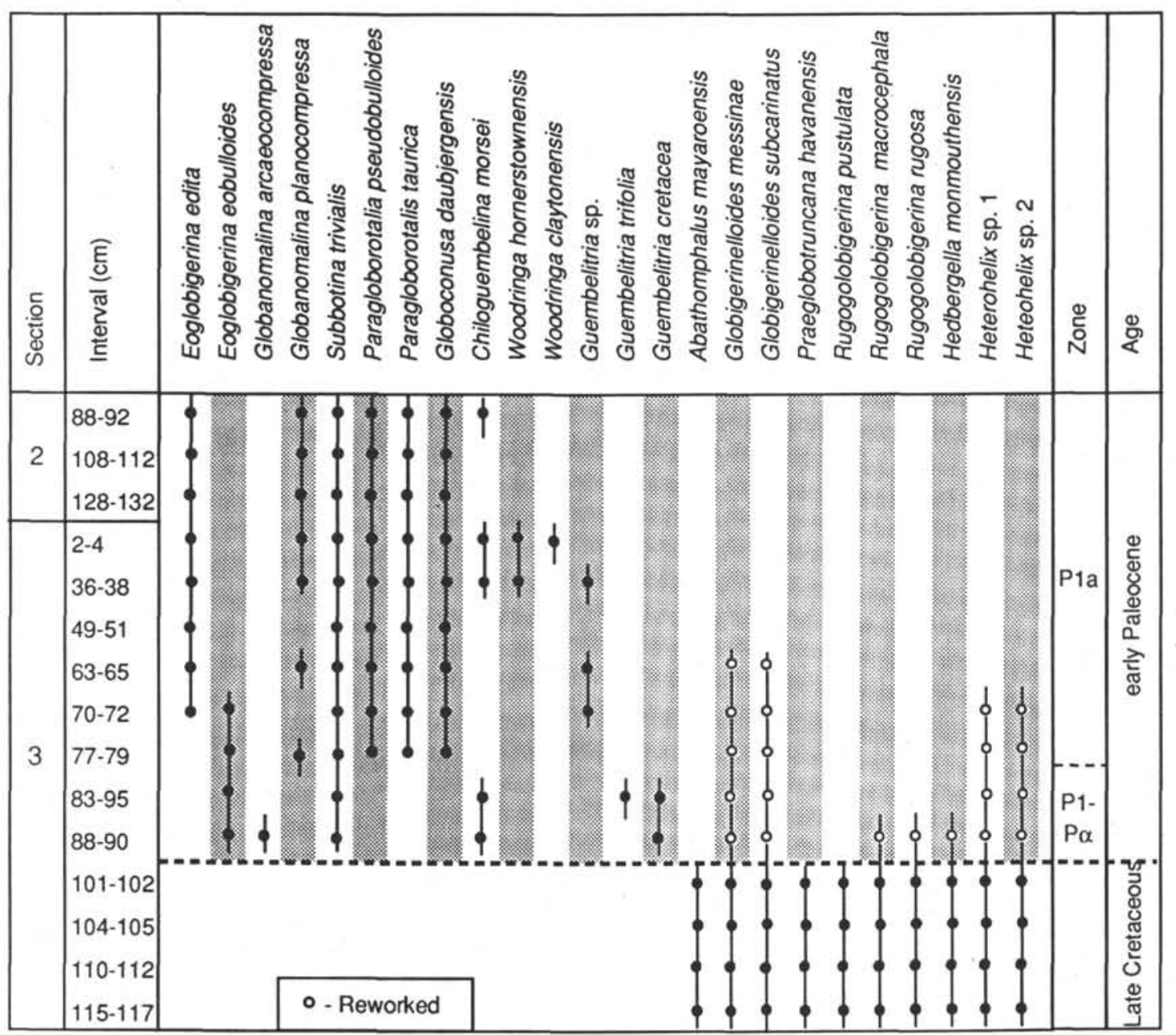

Figure 6. Range chart of planktonic foraminifers across the boundary at Hole 750A.

boundary occurs at the base of a 6-m-thick interval of volcanic ash and biogenic carbonate sediment that is bounded by more carbonate-rich sediments above and below. Calculations revealed that carbonate accumulation rates declined by nearly $90 \%$ across the boundary, remained low until the NP1/NP2 boundary, and suddenly increased twofold. Similar temporal patterns in carbonate accumulation rates have been recorded in Pacific and Atlantic pelagic and hemipelagic K/P boundary sequences (Zachos and Arthur, 1986).

The third perturbation recorded at the NP1/NP2 boundary is a gradual recovery of surface- to deep-water carbon isotope gradients, as recorded by planktonic and benthic microfossils (Figs. 8 and 9). Upper Maestrichtian samples show a robust $1.0 \%$ gradient between planktonic and benthic foraminifers, whereas early Danian samples show essentially no difference. Because most recent planktonic foraminifers precipitate their shells in near-isotopic equilibrium with ambient seawater, their measured values reflect relative distribution of surface seawater, total dissolved carbon (TDC) $\delta^{13} \mathrm{C}$ (Kahn and Williams, 1981; Fairbanks et al., 1982; Bouvier-Soumagnac and Duplessy, 1985). Benthic foraminifers also record the carbon isotopic composition of seawater TDC, although superimposed on the $\delta^{13} \mathrm{C}$ of benthic foraminifers that reside below the sediment/water interface are more negative values of sediment pore waters (e.g., Corliss, 1985; McCorkle et al., 1985). Thus, fossil planktonic and benthic foraminifer carbon isotope values provide a reasonable estimate of the isotopic compositions of paleo-surface and deep waters. At Site 750 the planktonic to benthic foraminifer $\delta^{13} \mathrm{C}$ gradient increased steadily beginning near the base of the NP2 Zone indicating that surface- to deep-water carbon isotope gradients had become reestablished. This event occurred at the same time carbonate accumulation rates increased (inferred from the color gradation), indicating that the net production rates of organic carbon and biogenic carbonate had recovered.

Furthermore, a comparison of the isotopic record with the calcareous nannofossil abundance record at Site 750 (Fig. 3) reveals a striking parallelism between the decrease in relative abundance of the persistent taxa between 349.60 and 349.10 mbsf and the increasing $\delta^{13} \mathrm{C}$ gradient. The absolute abundance patterns of the calcareous nannofossils (Figs. 5a and $5 \mathrm{~b})$, however, indicate that the reestablishment of the $\delta^{13} \mathrm{C}$ gradient between surface and deep oceanic waters is related to the increased abundance of incoming species in the genus Prinsius tenuiculum and is not related to the slow decrease in abundance of the persistent taxa. The sharp increase in absolute abundance of $P$. tenniculum between 349.60 and 349.17 mbsf parallels the increase in the $\delta^{13} \mathrm{C}$ gradient throughout the same interval. This apparent covariance suggests that open-ocean fertility is closely linked to surface-ocean trophic structure.

To compare the Site 750 carbon isotope record with lower latitude records, published carbon isotope records of two sites, Site 527 on the Walvis Ridge in the South Atlantic, and 
Table 3. Planktonic and benthic foraminifers and whole-rock (bulk) stable isotope data.

\begin{tabular}{|c|c|c|c|c|}
\hline $\begin{array}{l}\text { Core, section, } \\
\text { interval }(\mathrm{cm})\end{array}$ & $\begin{array}{l}\text { Depth } \\
\text { (mbsf) }\end{array}$ & Specimen & $\begin{array}{c}\delta^{18} \mathrm{O} \\
(\mathrm{PDB})\end{array}$ & $\begin{array}{c}\delta^{13} \mathrm{C} \\
(\mathrm{PDB})\end{array}$ \\
\hline \multicolumn{5}{|l|}{$120-750 \mathrm{~A}-$} \\
\hline $11 \mathrm{R}-1,20-24$ & 307.70 & Fine fraction & 0.34 & 2.21 \\
\hline $11 R-2,40-44$ & 309.40 & Fine fraction & 0.03 & 2.26 \\
\hline $12 \mathrm{R}-1,20-24$ & 317.40 & Fine fraction & 0.25 & 1.95 \\
\hline $12 \mathrm{R}-1,80-84$ & 318.00 & Fine fraction & 0.13 & 1.80 \\
\hline 12R-2, 20-24 & 318.90 & Fine fraction & -0.01 & 1.68 \\
\hline $12 \mathrm{R}-2,80-84$ & 319.50 & Fine fraction & -0.12 & 1.55 \\
\hline 12R-3, 20-24 & 320.40 & Fine fraction & 0.23 & 1.94 \\
\hline $12 \mathrm{R}-3,40-44$ & 320.60 & Fine fraction & 0.39 & 2.01 \\
\hline $12 \mathrm{R}-4,20-24$ & 321.90 & Fine fraction & 0.37 & 1.86 \\
\hline $12 \mathrm{R}-4,80-84$ & 322.50 & Fine fraction & 0.32 & 2.00 \\
\hline $13 \mathrm{R}-1,128-132$ & 328.08 & Fine fraction & 0.28 & 2.35 \\
\hline $13 R-2,40-44$ & 328.70 & Fine fraction & 0.34 & 2.37 \\
\hline $13 \mathrm{R}-2,128-132$ & 329.58 & Fine fraction & 0.36 & 2.29 \\
\hline $13 \mathrm{R}-3,80-84$ & 330.60 & Fine fraction & 0.22 & 1.96 \\
\hline $13 R-4,24-28$ & 331.54 & Fine fraction & 0.17 & 2.13 \\
\hline $14 \mathrm{R}-1,80-84$ & 337.30 & Fine fraction & 0.10 & 1.84 \\
\hline $14 \mathrm{R}-2,14-18$ & 338.14 & Fine fraction & 0.10 & 1.79 \\
\hline $14 \mathrm{R}-2,80-84$ & 338.80 & Fine fraction & 0.00 & 1.98 \\
\hline $15 \mathrm{R}-3,68-85$ & 349.93 & Fine fraction & -0.20 & 1.19 \\
\hline $14 \mathrm{R}-3,14-18$ & 339.64 & Whole rock & -0.10 & 1.91 \\
\hline $14 \mathrm{R}-3,80-84$ & 340.30 & Whole rock & 0.06 & 1.89 \\
\hline $14 \mathrm{R}-4,14-18$ & 341.14 & Whole rock & 0.13 & 2.17 \\
\hline $14 \mathrm{R}-4,80-84$ & 341.80 & Whole rock & 0.23 & 2.32 \\
\hline $15 \mathrm{R}-1,18-22$ & 346.28 & Whole rock & 0.20 & 2.43 \\
\hline $15 \mathrm{R}-1,38-42$ & 346.48 & Whole rock & 0.11 & 2.45 \\
\hline $15 \mathrm{R}-1,68-72$ & 346.78 & Whole rock & 0.39 & 2.50 \\
\hline $15 \mathrm{R}-1,95-99$ & 347.05 & Whole rock & 0.46 & 2.54 \\
\hline $15 \mathrm{R}-1,120-124$ & 347.30 & Whole rock & 0.46 & 2.51 \\
\hline $15 \mathrm{R}-2,8-12$ & 347.68 & Whole rock & 0.52 & 2.52 \\
\hline $15 \mathrm{R}-2,28-32$ & 347.88 & Whole rock & 0.34 & 2.43 \\
\hline $15 \mathrm{R}-2,48-52$ & 348.08 & Whole rock & 0.41 & 2.49 \\
\hline $15 \mathrm{R}-2,68-72$ & 348.28 & Whole rock & 0.36 & 2.55 \\
\hline $15 \mathrm{R}-2,88-92$ & 348.48 & Whole rock & 0.45 & 2.57 \\
\hline $15 \mathrm{R}-2,108-112$ & 348.68 & Whole rock & 0.37 & 2.54 \\
\hline $15 \mathrm{R}-2,128-132$ & 348.88 & Whole rock & 0.42 & 2.60 \\
\hline $15 \mathrm{R}-3,2-4$ & 349.12 & Whole rock & 0.30 & 2.47 \\
\hline $15 \mathrm{R}-3,36-38$ & 349.46 & Whole rock & -0.14 & 1.58 \\
\hline $15 \mathrm{R}-3,49-51$ & 349.59 & Whole rock & -0.21 & 1.29 \\
\hline $15 \mathrm{R}-3,56-58$ & 349.66 & Whole rock & -0.21 & 1.34 \\
\hline $15 R-3,63-65$ & 349.73 & Whole rock & 0.03 & 1.24 \\
\hline $15 \mathrm{R}-3,70-72$ & 349.80 & Whole rock & -0.13 & 1.10 \\
\hline $15 R-3,77-79$ & 349.87 & Whole rock & -0.13 & 1.18 \\
\hline $15 R-3,83-85$ & 349.93 & Whole rock & -0.17 & 1.16 \\
\hline $15 \mathrm{R}-3,88-90$ & 349.98 & Whole rock & -0.21 & 1.31 \\
\hline $15 \mathrm{R}-3,101-102$ & 350.11 & Whole rock & 0.52 & 2.13 \\
\hline
\end{tabular}

Site 577 on the Shatsky Rise in the northwest Pacific (Fig. 10), were compiled and plotted vs. age using published magnetobiostratigraphies and the most recent integrated time scale (Fig. 11; Berggren et al., 1985). The boundary sequences at these sites are complete, possessing all standard upper Maestrichtian and early Danian floral zones and magnetochrons, and show only minor reworking (e.g., Shackleton et al., 1984; Manivit and Feinberg, 1984; Zachos et al., 1985; Monechi, 1985; Bleil, 1985). The carbon isotope correlation between these sites is excellent; planktonic to benthic carbon isotope gradients show a rapid collapse at $66.4 \mathrm{Ma}$, remain near 0 to the base of the NP2 Zone (65.9 Ma), and then show a gradual return to normal by $65.7-65.5 \mathrm{Ma}$, similar in timing and magnitude to early Danian stable carbon isotope events at Site 750 where the carbon isotopic recovery occurred at or above the NP1/NP2 boundary. Thus, the lower Danian carbon isotope trends recorded at Site 690, Maud Rise, which suggest that recovery occurred much earlier in the southernmost Atlantic Ocean (Stott and Kennett, 1989, 1990a), appear to be anomalous and not representative of high latitudes in general.

In this regard, we note that recently published biostratigraphic data indicate that the earlier recovery of carbon
Table 3 (continued).

\begin{tabular}{|c|c|c|c|c|}
\hline $\begin{array}{l}\text { Core, section, } \\
\text { interval (cm) }\end{array}$ & $\begin{array}{l}\text { Depth } \\
\text { (mbsf) }\end{array}$ & Specimen & $\begin{array}{c}\delta^{18} \mathrm{O} \\
\text { (PDB) }\end{array}$ & $\begin{array}{c}\delta^{13} \mathrm{C} \\
\text { (PDB) }\end{array}$ \\
\hline 15R-3, 104-106 & 350.14 & Whole rock & -0.25 & 2.28 \\
\hline $15 \mathrm{R}-3,110-112$ & 350.20 & Whole rock & 0.16 & 2.15 \\
\hline $15 R-3,115-117$ & 350.25 & Whole rock & 0.16 & 2.01 \\
\hline $16 \mathrm{R}-1,26-30$ & 356.06 & Whole rock & -0.49 & 1.94 \\
\hline $16 \mathrm{R}-1,48-52$ & 356.28 & Whole rock & 0.19 & 2.41 \\
\hline $16 \mathrm{R}-1,68-72$ & 356.48 & Whole rock & 0.05 & 2.34 \\
\hline $15 R-2,48-52$ & 348.08 & N. truempyi & -0.11 & 1.53 \\
\hline $15 \mathrm{R}-2,88-92$ & 348.48 & N. truempyi & -0.14 & 1.52 \\
\hline $15 \mathrm{R}-2,108-112$ & 348.68 & N. truempyi & -0.16 & 1.47 \\
\hline $15 \mathrm{R}-2,128-132$ & 348.68 & N. truempyi & -0.13 & 1.37 \\
\hline $15 \mathrm{R}-3,2-4$ & 349.12 & N. truempyi & -0.13 & 1.43 \\
\hline $15 \mathrm{R}-3,36-38$ & 349.4 & N. truempyi & -0.29 & 1.25 \\
\hline $15 R-3,49-51$ & 349.59 & N. truempyi & -0.18 & 1.21 \\
\hline $15 \mathrm{R}-3,63-65$ & 349.73 & N. truempyi & -0.51 & 1.22 \\
\hline $15 \mathrm{R}-3,70-72$ & 349.80 & N. truempyi & 0.04 & 1.34 \\
\hline $15 \mathrm{R}-3,77-79$ & 349.87 & N. truempyi & 0.08 & 1.14 \\
\hline $15 \mathrm{R}-3,68-90$ & 349.98 & N. truempyi & -0.09 & 1.28 \\
\hline $16 \mathrm{R}-1,26-30$ & 356.06 & N. truempyi & 0.09 & 1.49 \\
\hline $15 \mathrm{R}-3,63-65$ & 349.73 & H. globulosa & -0.13 & 1.85 \\
\hline $15 \mathrm{R}-3,70-72$ & 349.80 & H. globulosa & -0.26 & 1.79 \\
\hline $15 \mathrm{R}-3,77-79$ & 349.87 & H. globulosa & -0.30 & 1.52 \\
\hline $15 \mathrm{R}-3,83-85$ & 349.5 & H. globulosa & -0.11 & 1.91 \\
\hline 15R-3, 68-90 & 349.98 & H. globulosa & -0.12 & 1.68 \\
\hline $15 R-3,101-102$ & 350.11 & H. globulosa & -0.22 & 2.09 \\
\hline $15 \mathrm{R}-3,104-106$ & 350.14 & H. globulosa & -0.41 & 1.68 \\
\hline $15 \mathrm{R}-3,110-112$ & 350.20 & H. globulosa & -0.50 & 1.94 \\
\hline $16 \mathrm{R}-1,26-30$ & 356.0 & H. globulosa & 0.18 & 1.75 \\
\hline $16 \mathrm{R}-1,48-52$ & 356.2 & H. globulosa & -0.02 & 1.82 \\
\hline $16 \mathrm{R}-1,80-81$ & 356.60 & H. globulosa & 0.12 & 1.70 \\
\hline $15 \mathrm{R}-3,49-51$ & 349.5 & S. beccariiformis & 0.00 & 0.97 \\
\hline $15 R-3,68-85$ & 349.9 & S. becc & 0.07 & 1.12 \\
\hline 15R-3, ic & 50.11 & S. bec & 0.02 & 1.24 \\
\hline $15 \mathrm{R}-3,10$ & 350.14 & S. becc & -0.32 & 1.11 \\
\hline $15 R-3,110-112$ & 350.20 & S. becc & -0.32 & 0.92 \\
\hline $16 \mathrm{R}-1,80-81$ & 356.60 & S. becce & 0.19 & 0.99 \\
\hline $15 \mathrm{R}-3,63-65$ & 349.73 & Globogerinelloides spp. & -0.55 & 2.23 \\
\hline $15 R-3,70-72$ & 349.80 & lloides spp. & -0.47 & 2.38 \\
\hline $15 \mathrm{R}-3,77-79$ & 349.87 & Globogeri & -0.54 & 2.32 \\
\hline $15 \mathrm{R}-3,68-85$ & 349.93 & erinelloides $\mathrm{sp}$ & -0.64 & 2.45 \\
\hline $15 \mathrm{R}-3,68-90$ & 349.98 & Globogerinelloides spp. & -0.47 & 2.47 \\
\hline $15 R-3,101-102$ & 350.11 & Globogerinelloides spp. & -0.44 & 2.39 \\
\hline $15 R-3,104-106$ & 350.14 & Globogerinelloides spp. & -0.36 & 2.52 \\
\hline $15 R-3,110-112$ & 350.20 & Globogerinelloides spp. & -0.65 & 2.08 \\
\hline 15R-3, 115-117 & 350.25 & Globogerinelloides spp. & -0.48 & 2.13 \\
\hline $15 \mathrm{R}-3,68-65$ & 349.73 & E. eobulloides & -0.22 & 1.58 \\
\hline $15 \mathrm{R}-3,70-72$ & 349.80 & E. eobulloides & -0.32 & 1.49 \\
\hline $15 \mathrm{R}-3,77-79$ & 349.87 & E. eobulloides & -0.19 & 1.50 \\
\hline $15 \mathrm{R}-3,68-85$ & 349.93 & E. eobulloides & -0.09 & 1.59 \\
\hline
\end{tabular}

isotope gradients at Site 690 may not be real but an artifact of a short-duration hiatus. Pospichal and Wise (1990), in an investigation of nannofossils from across the boundary at Site 690 , showed that the FADs of $C$. primus and $C$. tenuis occur at precisely the same level and in large abundances (also, the same level where the carbon isotope gradient recovers). Because the FAD of $C$. primus precedes that of $C$. tenuis in all complete K/P boundary sequences (Thierstein, 1981; Manivit and Feinberg, 1984; Monechi, 1985), Pospichal and Wise (1990) suggested that a hiatus was present at or near the NP1/NP2 boundary. This is critical because the carbon recovery consistently correlates with the NP1/ NP2 zonal boundary within Magnetochron $29 \mathrm{~N}$ at other pelagic $\mathrm{K} / \mathrm{P}$ boundary sequences. Stott and Kennett (1990a), however, used only the magnetostratigraphy and a modified high-latitude planktonic foraminifer zonation (Stott and Kennett, 1990b) to estimate sample ages at Site 690 while assuming a continuous record. In failing to recognize a hiatus and truncation of the younger part of Chron 29R, ages for samples from above the boundary were probably overestimated by as much as $200 \mathrm{k}$.y. A hiatus at the NP1/NP2 boundary (Chron $29 \mathrm{R}$ and $29 \mathrm{~N}$ boundary) would also explain two other unusual occurrences at Site 690: 


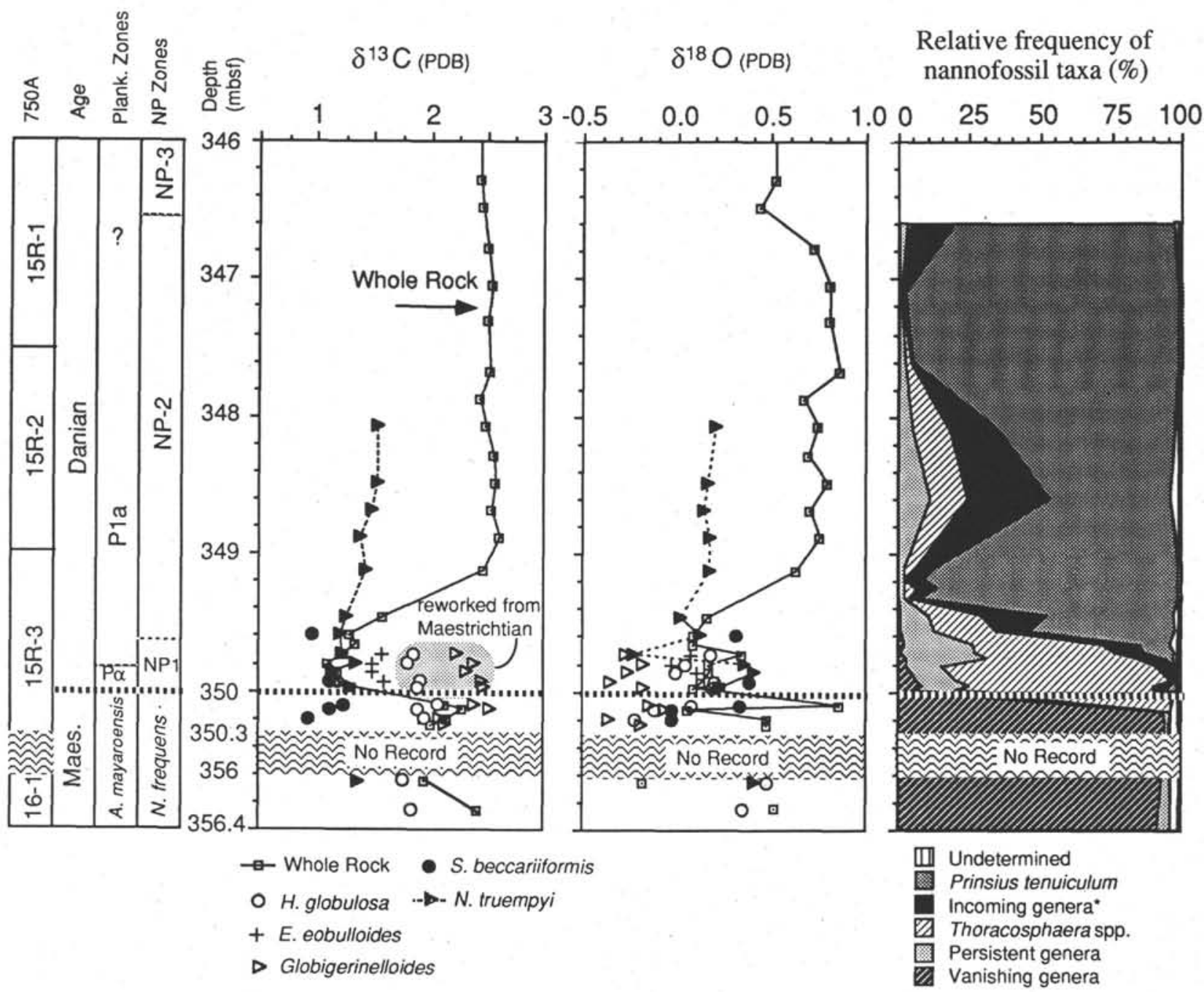

Figure 7. Whole-rock, fine-fraction $(<63-\mu \mathrm{m})$ planktonic and benthic foraminifer stable isotope values plotted along with the relative nannofossil abundances from Figure 4 vs. depth (346-356.4 mbsf) across the boundary at Site 750 .

(1) the seemingly instantaneous transition from low to normal carbon gradients, and (2) the high position of the K/P boundary in Chronozone 29R (C29.75R); at other $\mathrm{K} / \mathrm{P}$ boundary sequences the position of the $\mathrm{K} / \mathrm{P}$ boundary is substantially lower in the chron (C29.75R) (Hamilton, 1990; Channel and Dobson, 1989).

Investigators have suggested that the reduction of surface- to deep-water carbon isotope gradients at the $\mathrm{K} / \mathrm{P}$ boundary resulted from reduced marine productivity brought about by the mass extinction of plankton (Hsü et al., 1982a; Zachos and Arthur, 1986; Zachos et al., 1989). Such a reduction of organic carbon production and/or flux would not only eliminate partitioning of carbon isotopes between the surface- and deep-water reservoirs but between basins as well (Zachos et al., 1988; Stott and Kennett, 1990a). Paleodistribution of carbon isotopes between the deep-ocean reservoirs can be roughly estimated by plotting benthic foraminifer carbon isotope data from Sites 527, 577, and 750 (Fig. 12). In the late Maestrichtian, carbon isotope differences between basins were large $(\sim 1.0 \%)$, suggesting that some degree of basin-to-basin fractionation existed at that time. During much of the $0.5-\mathrm{m} . y$. post-boundary period, however, benthic foraminifer values were nearly homogeneous between the Atlantic and Pacific. No Site 750 data exist for the lower portion of NP-1 because of the hiatus, but values recorded over the upper part of Zone NP1 at Site 750 are similar to those recorded elsewhere. Once recovery began in Zone NP2, carbon isotope differences between the deep reservoirs reemerged, with the highest values in the Southern Indian Ocean. This confirms previous speculation that reduction of carbon isotope gradients between oceanic reservoirs in the earliest Danian was global, a transient state that could only be sustained while organic carbon fluxes between surface and deep reservoirs were low (Hsü et al., 1982a; Zachos et al., 1989). This evidence and the evidence of lowered carbonate accumulation rates discussed above further support a scenario of a worldwide period of low net productivity during the earliest Danian.

\section{SUMMARY}

Biostratigraphic records indicate a $0.3-\mathrm{m} . \mathrm{y}$. hiatus encompassing the lower portion of lower Danian Biozones NP1 and $\mathrm{P} \alpha$ and possibly a small part of the upper Maestrichtian at Hole 750A. The upper portion of nannoplankton Zone NP1 and all of NP2 and planktonic foraminifer Zone P1a appear to be intact. Carbon isotope data demonstrate that specimens of upper Maestrichtian planktonic foraminifers Heterohelix and Globigerinelloides in the lower Danian at Site 750 are re- 


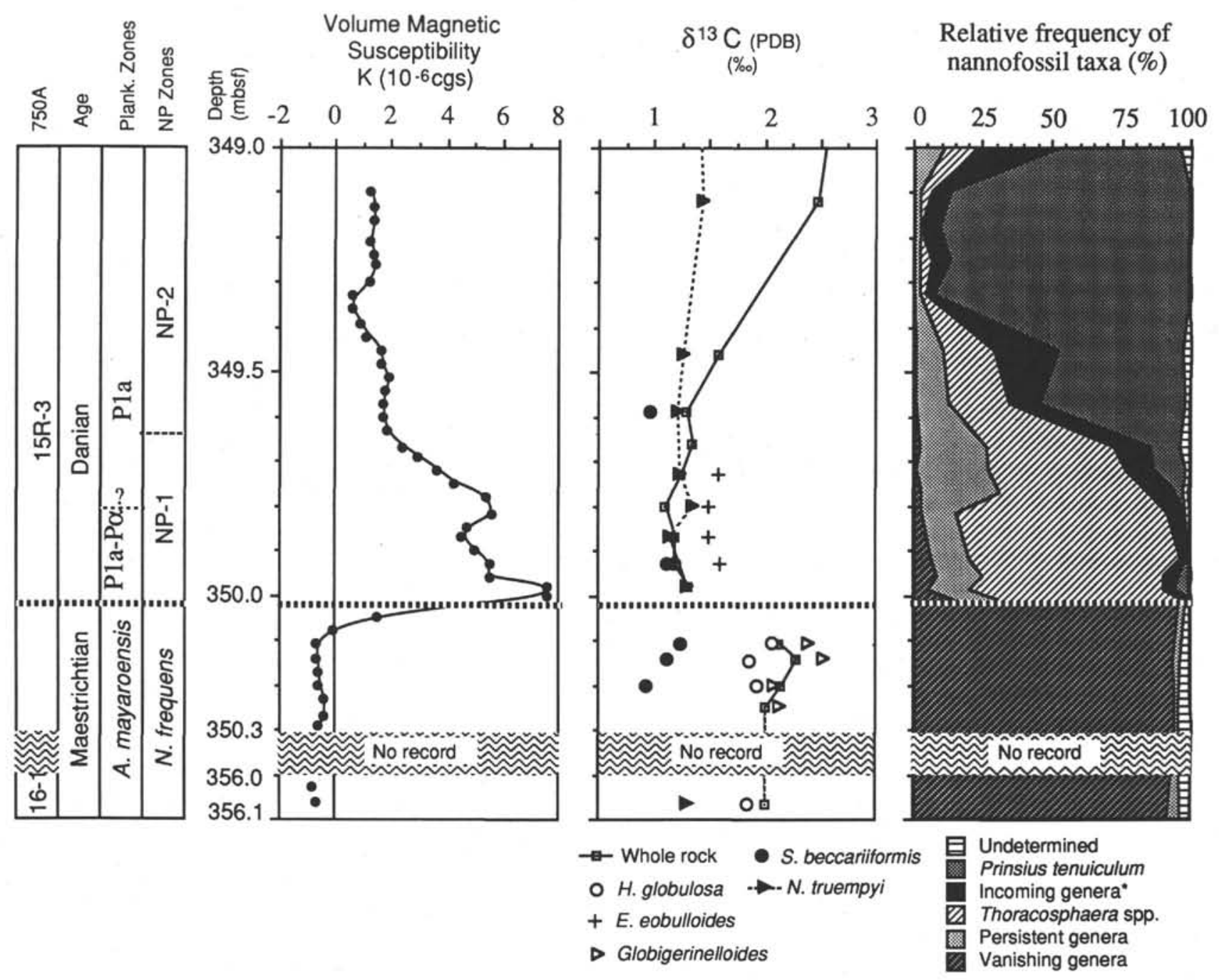

Figure 8. Whole-rock magnetic susceptibility $\mathrm{K}$ values, stable carbon isotope values, and absolute nannofossil abundances vs. depth (349-356 mbsf) across the K/P boundary.

worked. The NP1-NP2 zonal transition is marked by a gradual turnover in nannoplankton relative abundances, from predominantly persistent species (rare in the Cretaceous) to newly evolving Danian species. Carbonate contents and surface- to deep-water carbon isotope gradients declined across the $\mathrm{K} / \mathrm{P}$ boundary and did not begin to recover until the NP1-NP2 boundary about $0.5-\mathrm{m}, \mathrm{y}$. post-boundary $(\sim 65.9 \mathrm{Ma})$. The temporal relationship between faunal and floral evolution and geochemical changes recorded at Site 750 is similar to that observed in previously studied low- and mid-latitude $\mathrm{K} / \mathrm{P}$ boundary sequences, confirming the ubiquitous character of paleoenvironmental change following the $\mathrm{K} / \mathrm{P}$ boundary.

\section{ACKNOWLEDGMENTS}

We thank Paul Stebleton and James Burdett for technical assistance. Critical reviews by Ellen Thomas and Steve D'Hondt significantly improved the manuscript. All isotope analyses were conducted by the University of Michigan Stable Isotope Laboratory. This research was supported by JOIDESUSSAC Grant No. 20238.

\section{REFERENCES}

Arthur, M. A., Dean, W. E., Zachos, J. C., Kaminski, M., Rieg, S. H., and Elmstrom, K., 1989. Geochemical expression of early diagenesis in Middle Eocene-Lower Oligocene pelagic sediments in the southern Labrador Sea, Site 647, ODP Leg 105. In Srivastava, S. P., Arthur, M., Clement, B., et al., Proc. ODP, Sci. Results, 105: College Station, TX (Ocean Drilling Program), 111-135.

Barker, P. F., Kennett, J. P., et al., 1990. Proc. ODP. Sci. Results, 113: College Station, TX (Ocean Drilling Program).

Beaufort, L., in press. Adaptation of the random settling method for quantitative studies of calcareous nannofossils. Micropaleontology.

Berggren, W. A., Kent, D. V., Flynn, J. J., and Van Couvering, J. A., 1985. Cenozoic geochronology. Geol. Soc. Am. Bull., 96:14071418.

Berggren, W. A., and Miller, K. G., 1988. Paleogene tropical planktonic foraminiferal biostratigraphy and magnetobiochronology. Micropaleontology, 34:362-380.

Bleil, U., 1985. The magnetostratigraphy of northwest Pacific sediments, Deep Sea Drilling Project Leg 86. In Heath, G. R., Burckle, L. H., et al., Init. Repts. DSDP, 86: Washington (U.S. Govt. Printing Office), 441-458.

Bouvier-Soumagnac, Y., and Duplessy, J.-C., 1985. Carbon and oxygen isotopic composition of planktonic foraminifera from laboratory culture, plankton tows and recent sediment: implications for the reconstruction of paleoclimatic conditions and of the global carbon cycle. J. Foraminiferal Res., 15:302-320.

Channel, J.E.T., and Dobson, J. P., 1989. Magnetic stratigraphy and magnetic mineralogy at the Cretaceous-Tertiary boundary section, 
Braggs, Alabama. Palaeogeogr., Palaeoclimatol., Palaeoecol., 69:267-277.

Chave, A. D., 1984. Lower Paleocene-Upper Cretaceous magnetostratigraphy, Sites 525, 527, 528, and 529, Deep Sea Drilling Project Leg 74. In Moore, T. C., Jr., Rabinowitz, P. D., et al., Init. Repts. DSDP, 74: Washington (U.S. Govt. Printing Office), 525532.

Corfield, R. M., and Granlund, A. H., 1988. Speciation and structural evolution in the Palaeocene Morozovella lineage (planktonic Foraminiferida). J. Micropaleontol., 7:59-72.

Corliss, B. H., 1985. Microhabitats of benthic foraminifera within deep-sea sediments. Nature, 314:435-438.

Craig, H., 1957. Isotopic standards for carbon and oxygen and correction factors for mass spectrometric analysis of carbon dioxide. Geochim. Comochim. Acta, 12:133-149.

Dudley, W. C., Blackwelder, P. L., Brand, L. E., and Duplessy, J.-C., 1986. Stable isotopic composition of coccoliths. Mar. Micropaleontol., 10:1-8.

Fairbanks, R. G., Sverdlove, M., Free, R., Wiebe, P. H., and Bé, A.W.H., 1982: Vertical distribution and isotopic fractionation of living planktonic foraminifera from the Panama Basin. Nature, 298:841-844.

Gerstel, J., Thunell, R., and Ehrlich, R., 1987. Danian faunal succession: planktonic foraminiferal response to a changing marine environment. Geology, 15:665-668.

Goodney, D. E., Margolis, S. V., Dudley, W. C., Kroopnick, P., and Williams, D. F., 1980. Oxygen and carbon isotopes of Recent calcareous nannofossils as paleoceanographic indicators. Mar. Micropaleontol., 5:31-42.

Hamilton, N., 1990. Mesozoic magnetostratigraphy of Maud Rise, Antarctica. In Barker, P. F., Kennett, J. P., et al., Proc. ODP, Sci. Results, 113: College Station, TX (Ocean Drilling Program), 255-260.

Herbert, T. D., and D'Hondt, S. L., 1990. Environmental dynamics across the Cretaceous/Tertiary Boundary measured by 21,000 year climate cycles in sediments. Earth Planet. Sci. Lett., 99:263-275.

Hsü, K. J., He, Q., McKenzie, J. A., Weissert, H., Perch-Nielsen, C., Oberhänsli, H., Kelts, K., LaBrecque, J., Tauxe, L., Krähenbühl, U., Percival, S. F., Wright, R., Karpoff, A. M., Petersen, N., Tucker, P., Poore, R. Z., Gombos, A. M., Pisciotto, K., Carman, M. F., and Schreiber, E., 1982a. Mass mortality and its environmental and evolutionary consequences. Science, 216:249-256.

Hsü, K. J., McKenzie, J. A., and He, Q. X., 1982b. Terminal Cretaceous environmental and evolutionary changes. In Silver, L. T., and Schultz, P. H. (Eds.), Geological Implications of Impacts of Large Asteroids and Comets on the Earth. Spec. Pap. Geol. Soc. Am., 190:317-328.

Kahn, M. I., and Williams, D. F., 1981. Oxygen and carbon isotopic composition of living planktonic foraminifera from the northeast Pacific Ocean. Palaeogeogr., Palaeoclimatol., Palaeoecol., 33: 47-71.

Keller, G., 1989a. Extended K/T boundary extinctions across the Cretaceous/Tertiary boundary in planktonic foraminifera of continental-shelf sections: implications for impact and volcanism theories. Geol. Soc. Am. Bull., 101:1408-1419.

1989b. Extended K/T boundary extinctions and delayed population change in planktonic foraminiferal faunas from Brazos River, Texas. Paleoceanography, 4:287-332.

Kent, D. V., and Gradstein, F. M., 1985. A Cretaceous and Jurassic geochronology. Geol. Soc. Am. Bull., 96:1419-1427.

Killingley, J., 1983. Effects of diagenetic recrystallization on ${ }^{18} \mathrm{O} /{ }^{16} \mathrm{O}$ values of deep-sea sediments. Nature, 301:594-597.

Kroopnick, P., 1985. The distribution of ${ }^{13} \mathrm{C}$ of $\Sigma \mathrm{CO}_{2}$ in the world oceans. Deep-Sea Res. Part A, 32:57-84.

Manivit, H., and Feinberg, H., 1984. Correlation of magnetostratigraphy and nannofossil biostratigraphy in upper Cretaceous and lower Paleocene sediments of the Walvis Ridge area. In Moore, T. C., Jr., Rabinowitz, P. D., et al., Init. Repts. DSDP, 74: Washington (U.S. Govt. Printing Office), 469-474.

McCorkle, D. C., Emerson, S. R., and Quay, P., 1985. Stable carbon isotopes in marine porewaters. Earth Planet. Sci. Lett., 74:13-26.

Monechi, S., 1985. Campanian to Pleistocene calcareous nannofossil stratigraphy from the northwest Pascific Ocean, Deep Sea Drilling
Project Leg 86. In Heath, G. R., Burckle, L. H., et al. Init. Repts. DSDP, 86: Washington (U.S. Govt. Printing Office), 301-336.

Müller, G., and Gastner, M., 1971. The "Karbonat-bombe": a simple device for determination of the carbonate content in sediments, soils, and other materials. Neues Jahrb. Mineral. Monatsh., 10:466-469.

Paull, C. K., Hills, S. J., and Thierstein, H. R., 1988. Progressive dissolution of fine carbonate particles in pelagic sediments. Mar. Geol., 81:27-40.

Paull, C. K., and Thierstein, H. R., 1987. Stable isotopic fractionation among particles in Quaternary coccolith-sized deep-sea sediments. Paleoceanography, 2:423-429.

Perch-Nielsen, K., 1979. Calcareous nannofossil zonation at the Cretaceous/Tertiary boundary in Denmark. In Birkelund, T., and Bromley, R. G. (Eds.), Cretaceous-Tertiary Boundary Events (Vol. 1): Copenhagen (Univ. of Copenhagen), 115-135.

Perch-Nielsen, K., McKenzie, J. A., and He, Q. X., 1982. Biostratigraphy and isotope stratigraphy and the "catastrophic" extinction of calcareous nannoplankton at the Cretaceous/Tertiary boundary. In Silver, L. T., and Schultz, P. H. (Eds.), Geological Implications of Impacts of Large Asteroids and Comets on the Earth. Spec. Pap. Geol. Soc. Am., 190:353-371.

Pospichal, J. J., and Wise, S. W., Jr., 1990. Calcareous nannofossils across the K/T boundary, ODP Hole $690 \mathrm{C}$, Maud Rise, Weddel Sea. In Barker, P. F., Kennett, J. P., et al., Proc. ODP, Sci. Results, 113: College Station, TX (Ocean Drilling Program), 515-532.

Rea, D. K., Dehn, J., Driscoll, N. W., Janecek, T. R., Owen, R. N., Pospichal, J. J., Resiwati, P., and ODP Leg 121 Scientific Party, 1990. Paleoceanography of the eastern Indian Ocean from ODP Leg 121 drilling on Broken Ridge. Geol Soc. Am. Bull., 102:679690.

Schlanger, S. O., and Douglas, R. G., 1974. The pelagic ooze-chalklimestone transition and its implication for marine stratigraphy. In Hsü, K. J., and Jenkyns, H. C. (Eds.), Pelagic Sediments: On Land and Under the Sea. Int. Assoc. Sedimentol. Spec. Publ., $1: 177-210$.

Shackleton, N. J., and Hall, M. A., 1984. Carbon isotope data from Leg 74 sediments. In Moore, T. C., Jr., Rabinowitz, P. D., et al., Init. Repts. DSDP, 74: Washington (U.S. Govt. Printing Office), 613-619.

Shackleton, N. J., Hall, M. A., and Boersma, A., 1984. Oxygen and carbon isotope data from Leg 74 foraminifers. In Moore, T. C., Jr., Rabinowitz, P. D., et al., Init. Repts. DSDP, 74: Washington (U.S. Govt. Printing Office), 599-644.

Smit, J., 1977. Discovery of a planktonic foraminiferal association between the Abathomphalus mayaroensis Zone and the Globigerina eugubina Zone at the Cretaceous/Tertiary boundary in the Barranco del Gredero (Caravaca, SE Spain): a preliminary report I and II. Proc. K. Ned. Akad. Wet. Ser. B, 80:280-301.

1982. Extinction and evolution of planktonic foraminifera after a major impact at the Cretaceous/Tertiary boundary. In Silver, L. T., and Schultz, P. H. (Eds.), Geological Implications of Impacts of Large Asteroids and Comets on the Earth. Spec. Pap. Geol. Soc. Am., 190:329-352.

Stott, L. D., and Kennett, J. P., 1989. New constraints on early Tertiary paleoproductivity from carbon isotopes in foraminifera. Nature, 342:526-529.

1990a. The paleoceanographic and paleoclimatic signature of the Cretaceous/Paleogene boundary in the Antarctic: stable isotopic results from ODP Leg 113. In Barker, P. F., Kennett, J. P., et al., Proc. ODP, Sci. Results, 113: College Station, TX (Ocean Drilling Program), 829-848.

1990b. Antarctic Paleogene planktonic foraminifer biostratigraphy: ODP Leg 113, Sites 689 and 690. In Barker, P. F., Kennett, J. P., et al., Proc. ODP, Sci. Results, 113: College Station, TX (Ocean Drilling Program), 549-570.

Thierstein, H. R., 1981. Late Cretaceous nannoplankton and the change at the Cretaceous-Tertiary boundary. In Warme, J. E., Douglas, R. G., and Winterer, E. L. (Eds.), The Deep Sea Drilling Project: A Decade of Progress: Spec. Publ. Soc. Econ. Paleontol. Mineral., 32:355-394.

Worm, H.-U., and Banerjee, S. K., 1987. Rock magnetic signature of the Cretaceous-Tertiary boundary. Geophys. Res. Lett., 14:1083-1086. 
Zachos, J. C., and Arthur, M. A., 1986. Paleoceanography of the Cretaceous/Tertiary boundary event: inferences from stable isotopic and other data. Paleoceanography, 1:5-26.

Zachos, J. C., Arthur, M. A., and Dean, W. E., 1988. The Cretaceous-Tertiary Boundary marine extinction and global primary productivity collapse. In Global Catastrophes in Earth History: An interdisciplinary Conference on Impacts, Volcanism, and Mass Mortality. Snowbird, Utah, 223. (Abstract)

1989. Geochemical evidence for the suppression of pelagic primary productivity at the Cretaceous/Tertiary boundary. $\mathrm{Na}$ ture, 337:61-64.
Zachos, J. C., Arthur, M. A., Thunell, R. C., Williams, D. F., and Tappa, E. J., 1985. Stable isotope and trace element geochemistry at DSDP Hole 577, Leg 86. In Heath, G. R., Burckle, L. H., et al., Init. Repts. DSDP, 86: Washington (U.S. Govt. Printing Office), 513-532.

Date of initial receipt: 13 September 1990

Date of acceptance: 4 December 1990

Ms 120B-188 


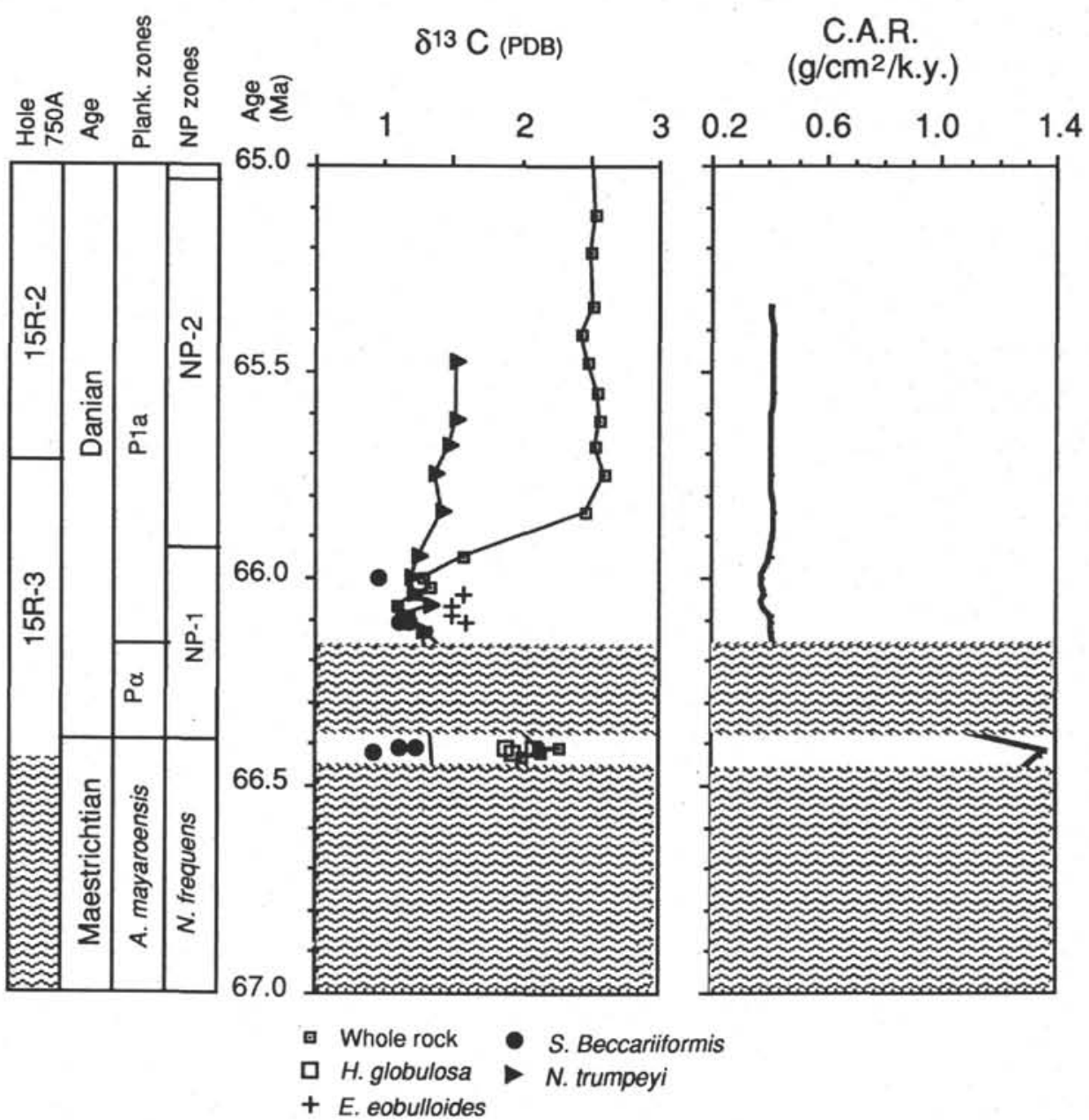

Figure 9. Site 750 stable carbon isotope values and carbonate accumulation rates vs. age (65-67 Ma) across the $\mathrm{K} / \mathrm{P}$ boundary. The age model is based on the nannofossil stratigraphy in the left column and the time scales of Berggren et al. (1985) and Kent and Gradstein (1985). The FAD of $N$. frequens is placed at $70 \mathrm{Ma}$ based on the recent findings of Poschipal and Wise (1990). Carbonate accumulation rates were calculated using the following equation: $\mathrm{CAR}=\% \mathrm{CaCO}_{3} / 100 \times \mathrm{DBD} \mathrm{g} / \mathrm{cm}^{3} \times \mathrm{S} \mathrm{cm} / \mathrm{yr}$, $\% \mathrm{CaCO}_{3}$ values, and physical properties measurements of dry-bulk density (DBD) (Part A).

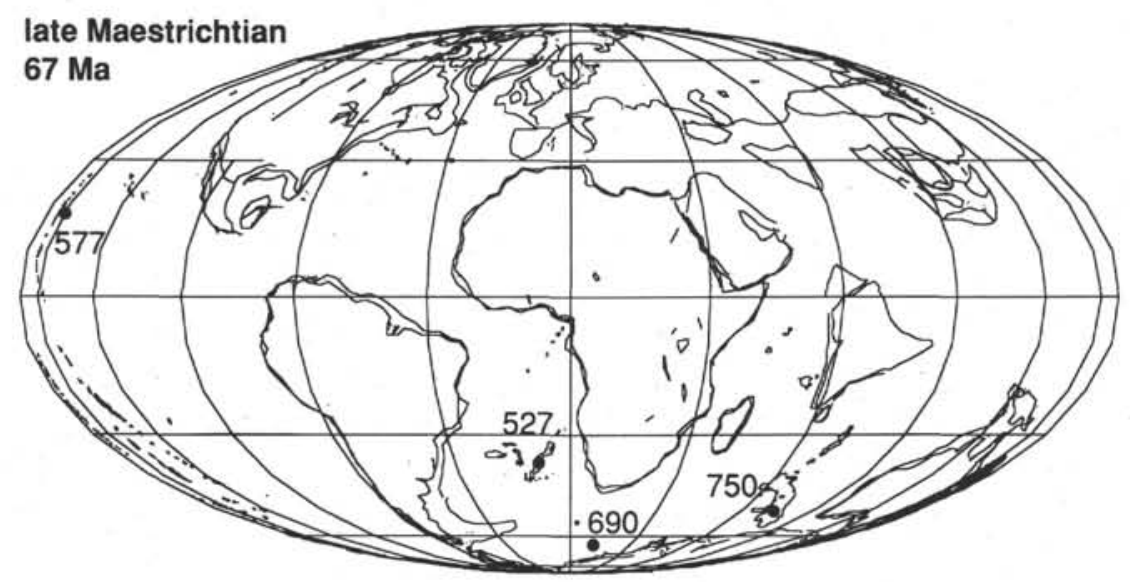

Figure 10. Paleoreconstruction of the late Maestrichtian showing the locations of Sites 527 (Walvis Ridge), 577 (Shatsky Rise), 690 (Maud Rise), and 750. 
Site 527

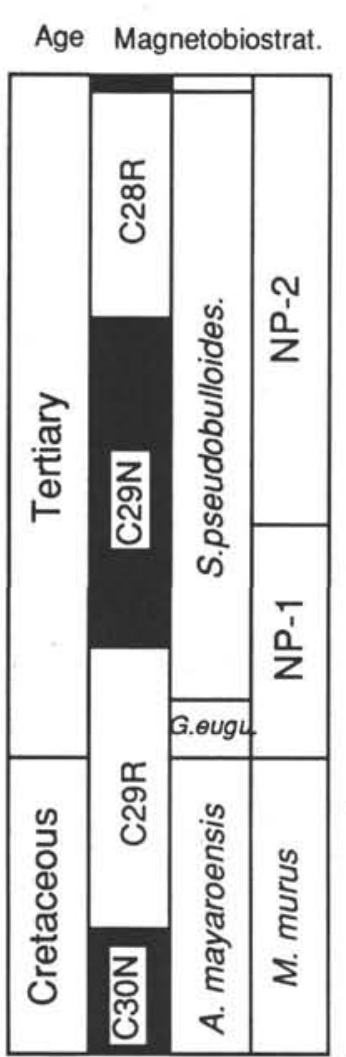

Site 577

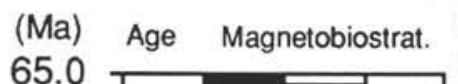

$\delta^{13} \mathrm{C}(\mathrm{PDB})$

(Ma) $0 \quad 1 \quad 2 \quad 3$

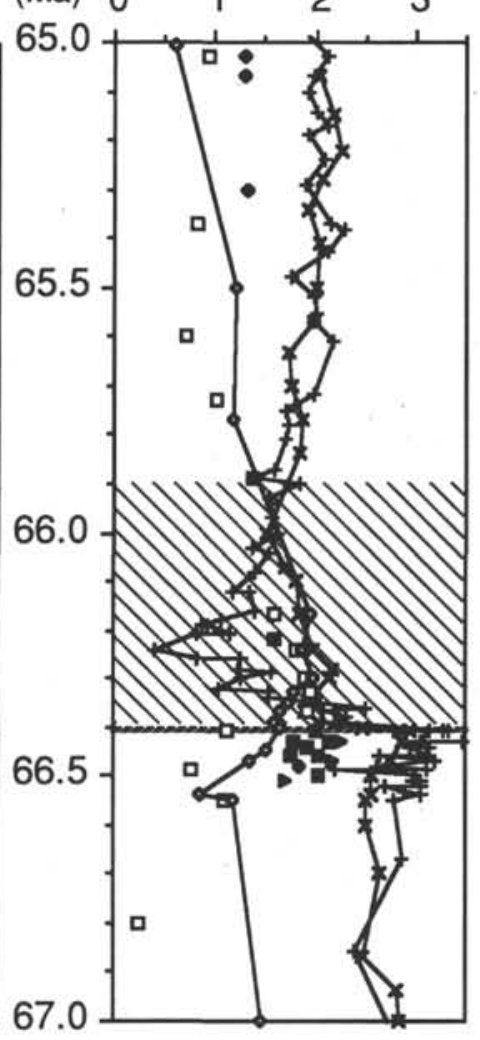

Site 527

† Bulk sample

- Mean

- Nuttallides+Gavelinella

- Nuttallides

(Shackleton et al.,1984;

Shackleton \& Hall, 1984)

Figure 11. Compilation of whole-rock, fine-fraction planktonic and benthic foraminifer stable carbon isotope data from Sites 527 (Walvis Ridge) and 577 (Shatsky Rise) vs. age (65-67 Ma) across the K/P boundary (Shackleton et al., 1984; Shackleton and Hall, 1984; Zachos et al., 1985, 1989). The age models for each site are based on the nanno- and magnetostratigraphies (Chave, 1984; Manivit and Feinberg, 1984; Bleil, 1985; Monechi, 1985) and the Berggren et al. (1985) time scale. 


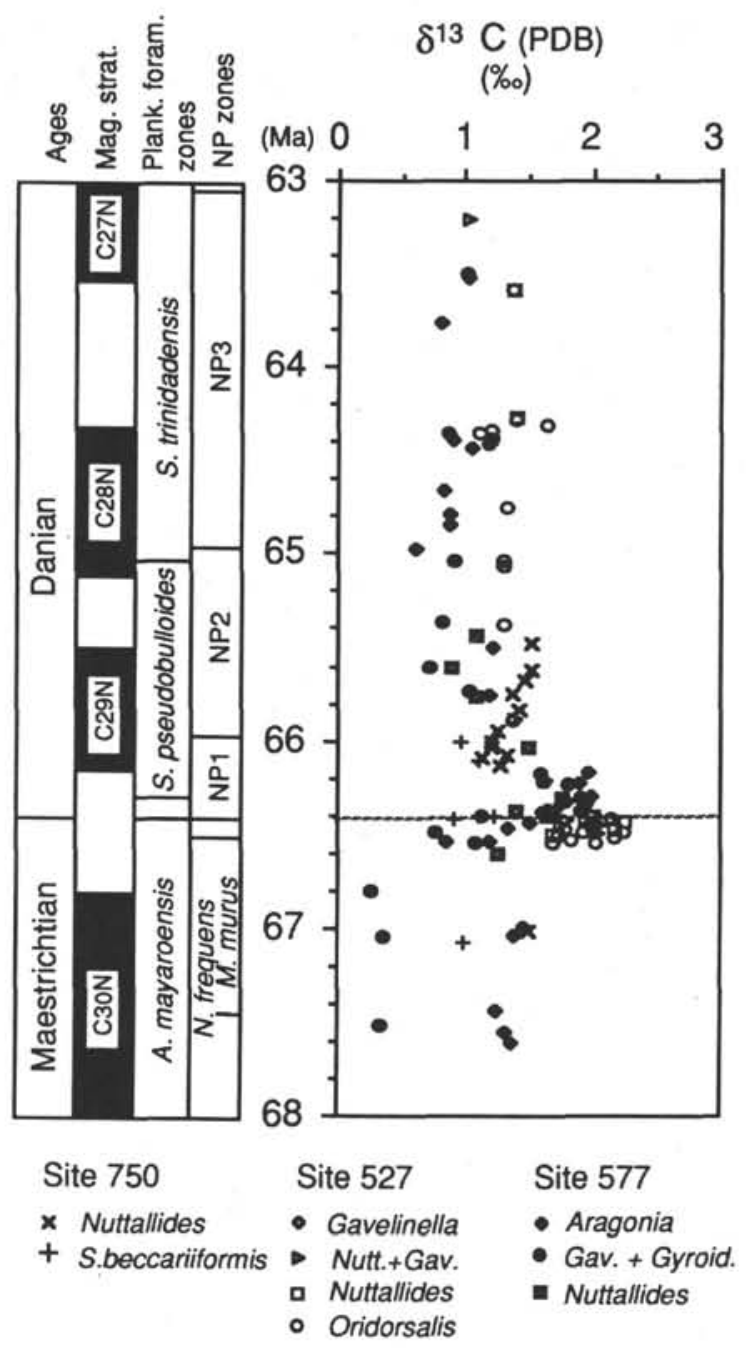

Figure 12. Compilation of benthic foraminifer carbon isotope data from Sites 527,577 , and 750 vs. age. The age models for Sites 527 and 577 are based on the nannofossil stratigraphies and magnetostratigraphies (Chave, 1984; Manivit and Feinberg, 1984; Bleil, 1985; Monechi, 1985 ) and the Berggren et al. (1985) and Kent and Gradstein (1985) time scales. 